\title{
Non-potable Water Quality Assessment Methodology for Water Conservation in Arid Climates
}

\author{
Geraldine Seguela ${ }^{1}$ (D) - J. R. Littlewood ${ }^{1} \cdot$ G. Karani ${ }^{2}$
}

Received: 18 June 2020 / Revised: 18 September 2020 / Accepted: 22 September 2020 / Published online: 6 November 2020

(C) The Author(s) 2020

\begin{abstract}
This paper documents a non-potable water (NPW) quality assessment methodology for a decentralized non-potable water system in Abu Dhabi (AD), capital city of the United Arab Emirates (UAE), which is dominated by sandy and salty soil, high temperature, and humidity. The context is a medical facility case study (MFCS) in AD, which includes a landscape $50 \%$ as large as its building footprint. The project identified the need to investigate the impact of air handling unit (AHU) air conditioning $(\mathrm{A} / \mathrm{C})$ condensate water $(\mathrm{CW})$ quality on soil health and building hydraulic systems. The aim of the research was to measure the impact of using recycled on-site NPW sources in a MFCS in AD, to alleviate the use of desalinated potable water and reduce associated energy consumption, operation cost, and greenhouse gas emissions for landscape irrigation (LI) and water feature (WF) use. CW has been tested in 2016 and in 2017 and analysed against local authority's parameter limits to establish suitability for LI and WF use. The findings are that in AD CW classification and characterization is a gap in knowledge whereby salinity and toxicity concentration limits should be addressed by the local authority because $\mathrm{CW}$ has an impact on soil infiltration rate due its low dissolved salt content as evidenced by the water test results. The recommendations for this paper are to develop a sustainable water conservation and reuse (SWC) strategy forming the basis for a water protocol by the competent authority for regional medical facility including a methodology for assessing on-site NPW quality for outdoor reuse to reduce soil infiltration problems and consequently conserve water and associated energy. The next steps are to confirm if the MFCS soil infiltration rate is affected by the CW or other factors, and to test additional NPW types.
\end{abstract}

Keywords Soil-water-energy nexus $\cdot$ Non-potable non-clinical wastewater reuse $\cdot$ Non-potable non-clinical water quality

\section{Introduction}

\section{Research Background}

Abu Dhabi (AD), the capital city and an Emirate of the United Arab Emirates (UAE), together with the Emirate of Dubai comprises over two-thirds (67\%) of the country's total population [1], which is mainly urban. $\mathrm{AD}$ is the largest of the seven Emirates occupying more than 80 percent (\%) of the

Geraldine Seguela

seguelag@gmail.com; geseguela@ cardiffmet.ac.uk

$1 \quad$ Cardiff School of Art \& Design, Sustainable and Resilient Built Environment group, Cardiff Metropolitan University, Western Avenue, Cardiff, UK

2 Environment \& Public Health Research group, Cardiff School of Health Sciences, Western Avenue, Cardiff, UK country's total land mass [2]. The climate of the UAE is arid (B) desert (W) and hot arid (h) (Bwh) as classified by Köppen and Geiger [3]. And its total renewable water resources per capita per year is one of the lowest $\left(15.96\right.$ cubic metres $\left.\left(\mathrm{m}^{3}\right)\right)$ among the world's 19 most water-scarce countries $[4,5]$.

Extremely low average rainfall, the depletion of limited groundwater resources, and the high demand for water have made the UAE including AD dependent on seawater desalination, which is highly energy intensive $[4,6]$. In this context, water conservation in the UAE has become a critical challenge [7] and solutions to conserve this precious resource have become a priority.

The medical facility case study (MFCS), a 364-bedroom hospital, with landscaping representing $50 \%$ of its building footprint is designed to be air treated condensate water, a product of air conditioning $(\mathrm{A} / \mathrm{C})$ for landscape irrigation (LI) and water features (WF) reuse, to avoid usage of any desalinated water in an arid environment. Due to peak condensate formation occurring in summer, there is a short fall 
availability in winter, which is proposed to be met firstly by soil amendment $[8,9]$, secondly by alternative non-potable water reuse and thirdly by building system audit. This is to reduce the use of potable water for outdoor use, to assess nonpotable water effect on plant growth, and to reduce building systems water and energy consumption, operation and maintenance cost and practices, and ultimately greenhouse gas emissions [10].

From the literature review conducted by the author $[11,12]$, it was found that the $\mathrm{AD}$ soil standard from the Ministry of Climate Change and Environment [13] does not clearly indicate minimum and maximum soil micro- and macronutrient concentration limits for soil maintenance. Moreover, the Regulation and Supervision Bureau [14] standard for water recycling does not include salinity water concentration limits, which is essential to conserve soil and can limit water consumption [15]. These two aspects point to the importance, from the authority, to direct operations and maintenance teams on water and soil quality requirements for UAE climatic conditions and to promote techniques to increase soil water holding capacity to prevent soil deficiency and soil infiltration problems, which impact on the environment [15-19].

The soil-water and energy-water nexus points to the need for a more unified water and soil conservation standard for cities such as AD. In order to investigate the quality of air handling unit (AHU) $\mathrm{A} / \mathrm{C}$ condensate for reuse, the research project used a mixed approach after Creswell and Plano Clark [20] and Creswell and Creswell [21] to collect data on water sources available at the MFCS. The water data collected was used to develop a sustainable water conservation and reuse (SWC) strategy that also includes the characterization and classification of the MFCS non-potable water, criteria to assess the MFCS water quality "fit for purpose" [22, 23], and the MFCS non-potable water treatment required for health riskfree reuse.

\section{Healthcare Context for Water Conservation}

As the design of the MFCS is based on standards from the United States of America (USA) these data resources are used. In a typical USA hospital, total water use can be segmented into five major categories: sanitary, heat ventilation air conditioning (HVAC), medical processes, cafeteria/food service, and laundry [24]. Figure 1 shows that $75 \%$ of potable water is used for medical equipment and mechanical systems, which means that for their intended use this water may not need to be potable, but of an acceptable quality [26]. Figure 2 shows that the largest use of potable water in hospitals is for cooling and heating equipment and plumbing fixtures and that $7 \%$ is used for landscaping [24].

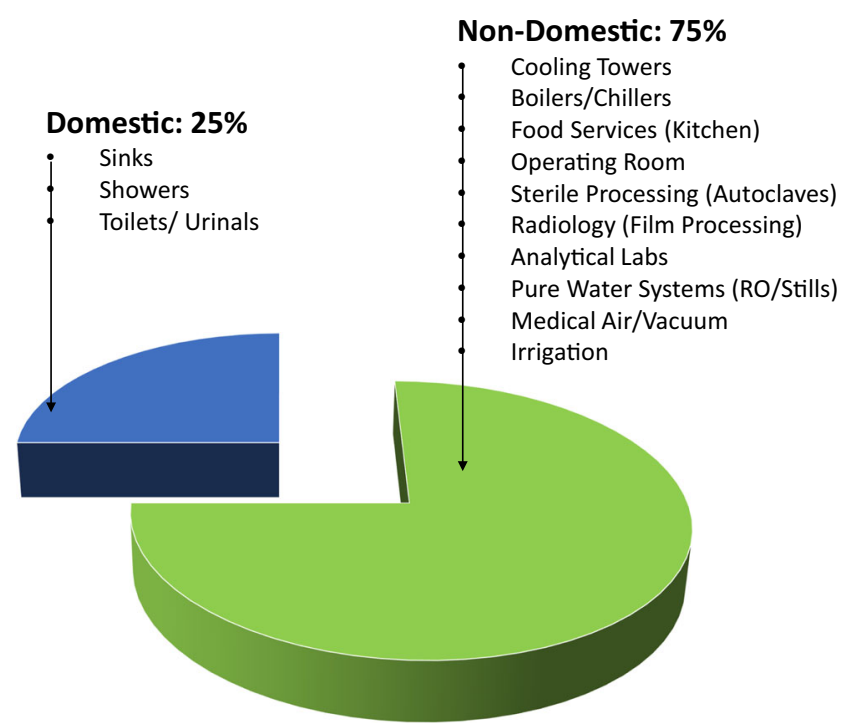

Fig. 1 Healthcare facility water use [25] in [12], p. 552

\section{The Case for Non-potable Water Recycling at the MFCS}

Based on Falkenmark and Widstrand [27] conventional definitions of levels of water stress, countries or regions are considered to be facing absolute water scarcity if renewable water resources are less than $500 \mathrm{~m}^{3}$ per capita, chronic water shortage if renewable water resources are between 500 and $1000 \mathrm{~m}^{3}$ per capita, and regular water stress between 1000 and $1700 \mathrm{~m}^{3}$ per capita [27]. Except for Iran and Iraq, all countries listed in Fig. 3 fall within the chronic water shortage definition including the UAE. In Abu Dhabi, capital city of the $\mathrm{UAE}$, the water consumption rate is 26 times the natural recharge capacity and $60 \%$ of the emirate's water consumption is used by the agriculture sector [4].

To release stress on the groundwater supply and to ease its dependence on seawater desalination, $\mathrm{AD}$ uses treated sewage effluent (TSE) to supply some of the demand [4, 28-31].

\section{END USES OF WATER IN HOSPITALS}

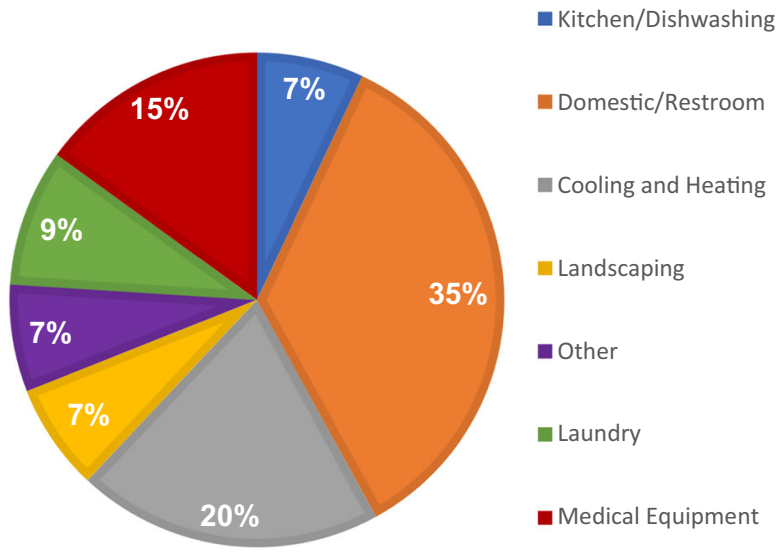

Fig. 2 End uses of water in hospitals [22] 

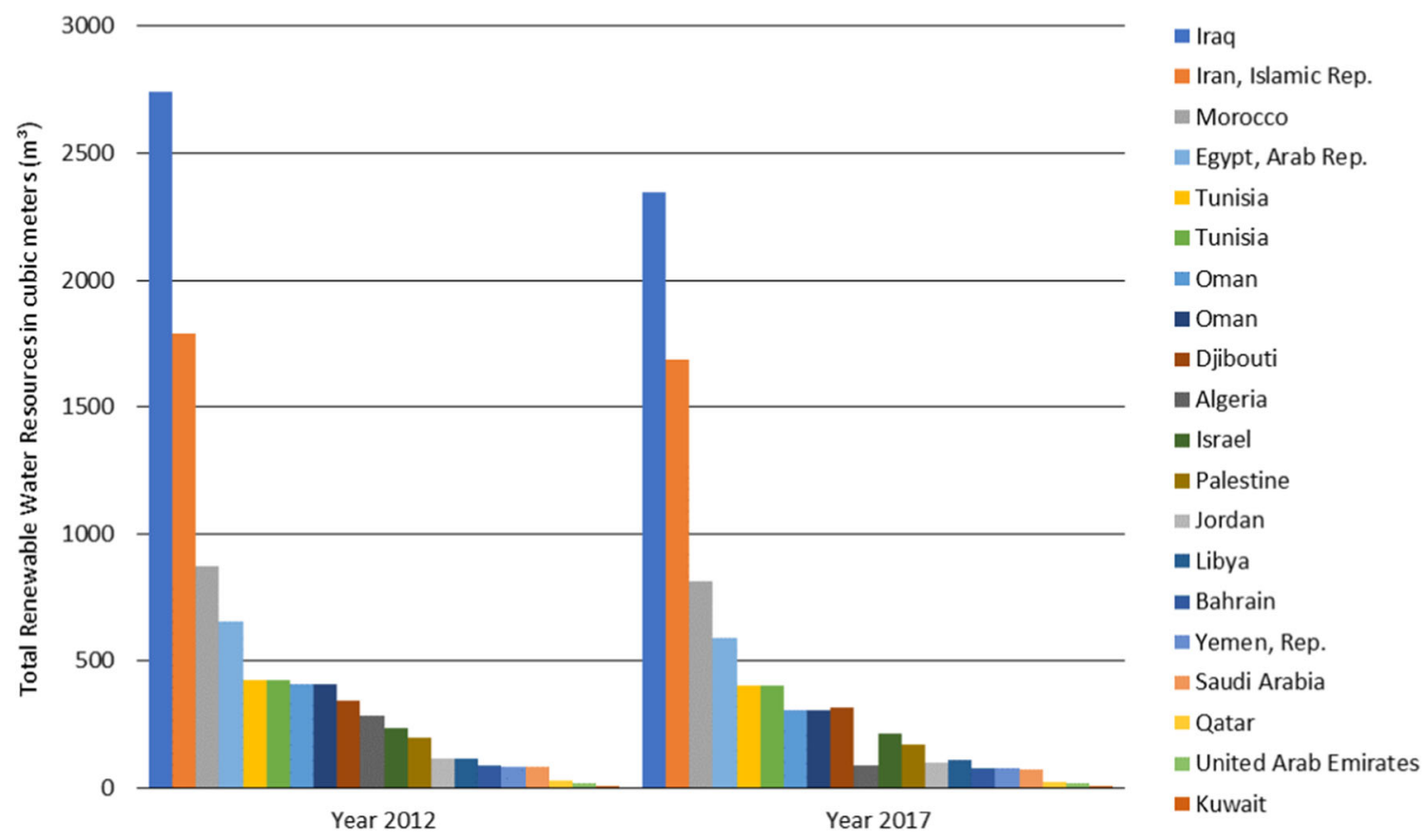

Fig. 3 Total renewable water resources per capita per year [5]

However, in 2012 it was reported (Environment Agency-Abu Dhabi [32] that $48 \%$ of TSE was returned to the environment, because the quality of recycled water produced contained raised levels of heavy metals and high total dissolved solids (TDS) due to infiltration of salty water in the sewage network $[32,33]$. Yet, discharging TSE in the environment is detrimental to human health and environmental pollution. Firstly, pollutants (toxic compounds, pathogens, heavy metals, nutrients, chemicals) can harm living organism and the aquatic environment [34], and secondly, accumulating and acidulating heavy metals can pollute soil [33, 34]. Jasim et al. [34] claimed that the energy required to treat TSE using conventional activated sludge system and microfiltration/ ultrafiltration (MF/UF) and reverse osmosis (RO) treatment system $\left(0.8\right.$ to $\left.1.2 \mathrm{kWh} / \mathrm{m}^{3}\right)$ is much lower than the production of desalinated water. TSE is also said to be beneficial for enriching agriculture soil (ibid.). The presence of macromicronutrients in the TSE water can improve soil condition and plant growth. TSE can also reduce the need for fertilizers, which is associated with chemical run off $[33,34]$ responsible for polluting rivers and coastal waters [35].

The main sewage treatment plant in $\mathrm{AD}$ is a conventional activated sludge treatment plant with sand filtration and chlorination, where the effluent complies with the Regulatory and Supervision Bureau [14] Recycled Water and Biosolids Regulations. Yet this technology is said to be ineffective to remove pharmaceuticals and personal care products (PPCPs) and persistence organic pollutants (POPs) [34, 36, 37]. A study by Salem et al. [37] found traces of PPCPs within 60 samples collected at two wastewater treatment plants in $\mathrm{AD}$ and $\mathrm{Al}$ Ain. In 2014, there was no published data on the trace of POPs in AD wastewater [36]. In 2020, there is still no published data as evidence by the Regulatory and Supervision Bureau [14] standard. POP and PPCP acceptable concentrations are currently not included in the Regulatory and Supervision Bureau [14] Recycled Water and Biosolids standard. In 2017, the AD Municipality (ADM) announced that in 2018 LI and streetscape will be provided by TSE at $80 \%$ in $\mathrm{AD}$ [38]. As such it will be mandatory to use TSE for LI [39]. At the time of this publication, there is no TSE infrastructure near the MFCS location and the timing for this to happen is presently (July 2019) unknown to the community $[40,41]$.

\section{Gap Analysis Leading to Change in Practice}

Through observations at the MFCS and by examination of Abu Dhabi buildings codes, standards, and guidelines, it became evident that there was a lack of water conservation directions from the authority to the public (see Table 1 for authority listing).

Whilst the Dubai Municipality [46] mandated all new buildings with a cooling load equal to or greater than three hundred fifty (350) kilowatts ( $\mathrm{kW}$ ) to recover condensate water for irrigation, LI, and toilet flushing, in Abu Dhabi, the standards and codes either conflict with each other or ignore one another. In relation to the gaps in practice identified in Table 1 , in $\mathrm{AD}$, it is not clear if $\mathrm{AHU} \mathrm{A} / \mathrm{C}$ condensate water reuse is considered wastewater or not, by local authorities [14, 42]. This is because wastewater is defined as "The waterborne wastes generated by any domestic, commercial or industrial activity including Grey Water and Trade Effluent" 
Table 1 Local standards and policies gap analysis related to non-potable water quality in AD

\begin{tabular}{|c|c|c|}
\hline $\begin{array}{l}\text { Existing codes, standards, and } \\
\text { strategies }\end{array}$ & Local water conservation regulation gaps & References \\
\hline Water Standard & $\begin{array}{l}\text { This standard does not address non-potable water reuse, but only prohibits the reuse } \\
\text { of wastewater. Yet Health Authority Abu Dhabi (HAAD) authorized the reuse } \\
\text { of treated condensate water for LI and WF use at the MFCS. }\end{array}$ & {$[42]$} \\
\hline $\begin{array}{l}\text { Guide to Recycled Water and } \\
\text { Biosolids Regulations } 2010\end{array}$ & $\begin{array}{l}\text { Regulation and Supervision Bureau (RSB) does not address non-potable water } \\
\text { reuse, but wastewater only. No classification or characterization of different } \\
\text { non-potable water types. }\end{array}$ & {$[14]$} \\
\hline $\begin{array}{l}\text { Guide to Recycled Water and } \\
\text { Biosolids Regulations } 2010\end{array}$ & $\begin{array}{l}\text { Beyond the potential for hydrogen }(\mathrm{pH}) \text { and copper, RSB does not offer other } \\
\text { parameter limits such as electrical conductivity, sodium, calcium, and magne- } \\
\text { sium concentrations, which influences water holding capacity in soil [12]. }\end{array}$ & {$[14]$} \\
\hline $\begin{array}{l}\text { International Building Code 2013, } \\
\text { Chapter } 29 \text { Plumbing Systems }\end{array}$ & Air conditioning condensate water is not addressed for use for toilet flushing reuse. & $\begin{array}{l}\text { Department of Municipal } \\
\text { Affairs and Transport [43] }\end{array}$ \\
\hline $\begin{array}{l}\text { The Water Resource Strategy } \\
\text { 2014-2018 }\end{array}$ & $\begin{array}{l}\text { The strategy includes treated wastewater (such as TSE from public network) } \\
\text { recycling only. }\end{array}$ & $\begin{array}{l}\text { Environment Agency-AD, } \\
\text { [39] }\end{array}$ \\
\hline $\begin{array}{l}\text { Uniform Plumbing Code of AD } \\
\text { Emirate }\end{array}$ & $\begin{array}{l}\text { Greywater storage is authorized for } 72 \mathrm{~h} \text { maximum. Condensate water storage is } \\
\text { not fully addressed, but essentially rainwater. It is not clear under which category } \\
\text { condensate water falls under. }\end{array}$ & {$[44]$} \\
\hline $\begin{array}{l}\text { Pearl Building Rating System } \\
\text { Guideline }\end{array}$ & $\begin{array}{l}\text { Water-saving strategy implementations are elective, not mandatory. UPC does not } \\
\text { address water alternative non-potable water reuse but treated sewage effluent } \\
\text { (TSE) only. }\end{array}$ & Urban Planning Council [45] \\
\hline Design Public Realm Guideline & $\begin{array}{l}\mathrm{A} / \mathrm{C} \text { condensate water reuse is proposed as a non-potable source for landscape } \\
\text { irrigation reuse with no special requirements on treatment and/or care for reuse. }\end{array}$ & {$[45]$} \\
\hline
\end{tabular}

([14], p.11). Yet medical facilities are authorized for reusing AHU A/C condensate water, subject for the system being maintained [47] to international and American Society of Heating Refrigerating and Air Conditioning Engineers [48] standards and codes, to prevent Legionella disease [43]. However, this is not clearly defined in any other Abu Dhabi guidelines, codes, standards, or laws as mentioned in Table 1 except in the Department of Municipal Affairs and Transport [43] building code (2013, Chapter 29). Whilst DMAT [43]) does not define AHU A/ $\mathrm{C}$ condensate water end use, RSB as the regulator of potable water and wastewater use and reuse does not either. The extent to which the Recycled Water and Biosolids Regulations [14] regulates landscape irrigation (LI) is by including criteria for trace elements. But no concentration values are defined for salinity or essential nutrients, which could be beneficial or toxic to plants and soils [15, 16, 49]. In addition, $\mathrm{AHU} \mathrm{A} / \mathrm{C}$ condensate water is not defined and classified according to international standards such as American Water Works Association [50] definitions and other international codes and standards such as San Antonio Plumbing Code (SAPC) [51]; Texas Administrative Code (TAC) Texas Commission on Environmental Quality [52]; International Green Construction Code (IGCC) International Code Council [53]; ASHRAE 189.1: International Green Construction Code [53]; Green Plumbing and Mechanical Code Supplement (GPMCS) International Association of Plumbing and Mechanical Official [54]; and NSF
Standards 350: On-site. Residential and Commercial Water Reuse Treatment Systems and NSF Standards 350.1: Onsite Water Reuse [55].

Whilst AHU A/C condensate water reuse is proposed as a non-potable source for landscape irrigation reuse in the [45]), the Pearl Building Rating System [45] makes it optional and rejects the reduction in potable water by recycled water as a prerequisite, because it is assumed projects will use TSE, i.e. the municipality treated wastewater. In addition, [43]) DMAT encourages the reuse of condensate water, a strategy not reflected within the Estidama program [45] nor in any other Standard. Department of Municipal Affairs and Transport [43] Plumbing Systems Chapter 29 refers to the AD Uniform Plumbing Code [44] and ASHRAE. American Society of Heating, Refrigerating and Air-Conditioning Engineers [48]. DMAT also refers to the Urban Planning Council [45] Public Realm Design Manual for water conservation in landscaping and more particularly to water recycling as TSE reuse. Thus, the only common ground of DMAT, RSB, Health Authority AD [47], and EAD is the regulation of Legionella for potable water and wastewater and the reuse of TSE. Moreover, the health authority (HAAD) released an updated standard in early 2012 on the use of wastewater in the Emirate of $\mathrm{AD}$, which prohibits treated or untreated wastewater reuse [42]. Whilst the MFCS was authorized by HAAD and RSB to reuse AHU A/C condensate water, the TSE connection to Maryah island (MFCS location) was in 2017 unknown [41]. 


\section{Original and Significant Contribution to Changes in Practice}

The key original and significant contributions to change in practice from the author's research are to propose a water conservation and reuse (WCS) strategy forming the basis for a water protocol, specific to arid climate regions such as $\mathrm{AD}$, and which addresses the following:

- The development and application of an outdoor water supply strategy to promote the reuse of selected nonclinical non-potable water sources for LI and WF use, to reduce the need for desalinated water use, by testing and analysing various non-clinical non-potable water resources on-site, and providing an account of their physical, salinity, sanitary, and microbiological characterization for their intended reuse.

\section{Methodology}

\section{Mixed Method Research}

To analyse and evaluate the potential for reusing the AHU A/ $\mathrm{C}$ condensate water for landscape irrigation (LI) and water features (WF), a series of interventions through action research methodology for case studies 1 and 2 have been implemented from January 2016 to January 2018. The Case Study 1 (CS1: Water Resources) and Case Study 2 (CS2: Water Quality) use a quantitative and qualitative data collection process respectively $[20,21]$ as illustrated in Fig. 4.

By triangulating $[57,58]$ the two case studies (CS1 and $\mathrm{CS} 2$ ) to the research for water resources and water quality, the MFCS outcome is the quantification of water consumption by flow meters monitoring and of the energy consumption in water PP3 and Intervention 3. This paper will address CS2 essentially with respect to their water quality assessment methodology.

\section{CS1 Intervention 1: 2017 Water Balance}

The MFCS implies undertaking a comparison of an on-site recycled water system as opposed to the use of municipal desalinated potable water to reduce environmental impact, energy consumption, operation maintenance, greenhouse gases emissions, and cost savings. This includes the development of a water balance (CS1 Intervention 1), which has been updated since 2016 results (CS1 PP1 in [11]; 2019a). In 2017, the water balance comprised 4 elements as illustrated in Fig. 5, A to D. The data was collected and analysed via existing and new sub flow meters installed in January 2017 (new flow meters 1, 2, 6, and 7 and existing flow meters 3, 4, and 5). The data was captured via the energy monitoring and control system (EMCS) daily. The Water Resources Case Study (CS1) focuses on elements A, B, C, and D, whereas the Water Quality Case Study (CS2) on A and D.

\section{Case Study 2 (CS2): Water Quality}

The Case Study 2 includes one pilot empirical study [58] and one intervention as detailed below and graphically represented in Fig. 4.

- CS2 PP3, Pilot Empirical Study 3 (AHU A/C Condensate Water Quality Testing and Analysis): April 2016 AHU A/ $\mathrm{C}$ condensate water testing during the implementation of CS1 Pilot Empirical Study 2 (PP2) (April-September 2016). This will include testing and analysing of existing $\mathrm{A} / \mathrm{C}$ condensate water quality. A study to assess on-site generated $\mathrm{A} / \mathrm{C}$ condensate water quality in a desert type climate, for outdoor reuse and its effect on the MFCS water system, soil, and plant growth

- CS2 Intervention 3 (AHU A/C Condensate Water Quality Testing and Analysis), March and June 2017: existing $\mathrm{AHU} \mathrm{A} / \mathrm{C}$ condensate water source. This will include testing and analysing the existing $\mathrm{AHU} \mathrm{A} / \mathrm{C}$ condensate water quality. A study to assess on-site generated non-potable water quality in a desert type climate, for outdoor reuse and its effect on the MFCS water system, soil, and plant growth.

\section{Water Sampling}

$\mathrm{A} / \mathrm{C}$ condensate water and desalinated water have been sampled at the MFCS and tested by an independent certified Emirates Authority for Standardization and Methodology (ESMA) laboratory.

The condensate water quality has been evaluated against the maximum allowable concentration or characteristic of Restricted Substances as specified in Schedule A1 and A2 of the Recycled Water and Biosolids Regulations [14] and against the desalinated water quality sampled and tested at the MFCS in March 2016.

\section{Non-potable Water Treatment Risk Assessment Method}

Non-clinical non-potable water can carry pathogenic microorganisms such as Legionella, which can proliferate in warm water such as water storage tanks and through aerosol systems such as sprinkler irrigation systems $([43,59,60,61,62])$.

Biodegradable organic material creates biochemical oxygen demand (BOD) concentrations in water [22]. BOD is the oxygen demand for bacteria to decompose the biodegradable organic matter $(\mathrm{BOM})$ in the water under standard 


\section{CASE STUDY ONE (CS1): WATER RESOURCES}

\section{Water Balance}

Pilot Empirical Study One: PP1 2016

2016 Water Balance (Seguela et al, 2017c) and Hydraulic Review (partly EMCS records and 2014 theoretical model) [January-December 2016 (12 months)]

\section{Intervention One:}

- 2017 Water Balance [EMCS records February 2017- January 2018 (12 months)];

- 2017 Non-Potable Water System Enhancement (July 2017- April 2018).

Fig. 4 Proposed research strategy summary [56]

conditions (5 days at $20^{\circ} \mathrm{C}$ ) [15]. BOD is used to determine the relative oxygen requirements for aerobic decomposition for biodegradable organic matter or pollutants that may contain suspended or dissolved organic chemicals (ibid.). The chemical oxygen demand (COD) includes BOM and any
CASE STUDY TWO (CS2): WATER QUALITY

\section{Non-Potable Water Quality}

Pilot Empirical Study Three: PP3

- Pilot A/C Condensate Water Quality Testing (May 2016) (Seguela et al, 2017a).

- Intervention Three:

A/C Condensate Water \& Additional Non-Potable

Water Quality Testing (March and June 2017) (Seguela 2018)
Fig. 5 CS1 Intervention 1 Water Balance methodology (adapted from [8], p.554)

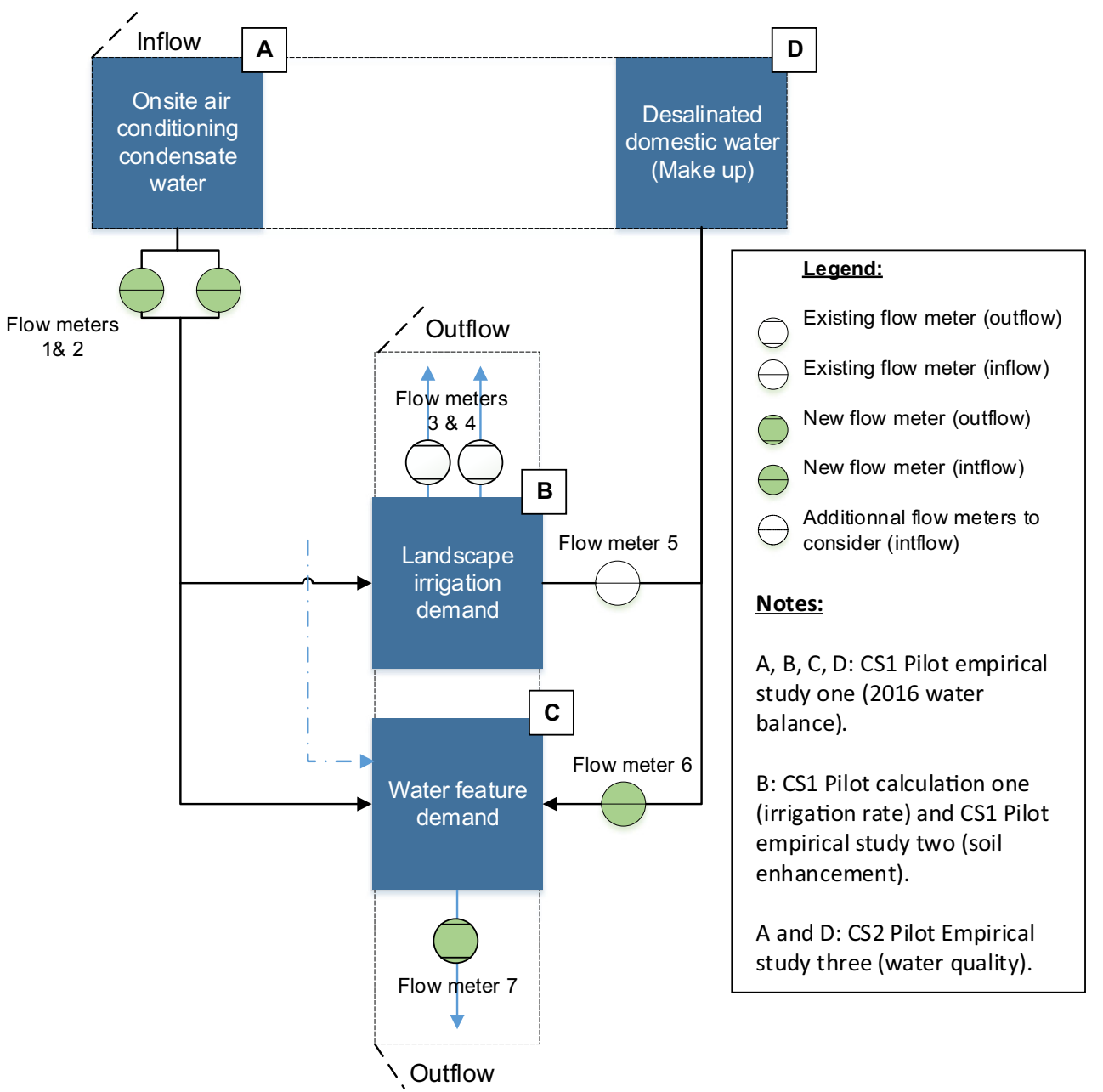

other organic matter or inorganic materials that may be oxidized by a strong oxidizing agent and not just by bacteria and that is why COD are higher than BOD values. The dissolved oxygen (DO) indicates the level of oxygen in water body (ibid.). For irrigation water, this broad indicator is used to 
determine the health of a water body, but it does not determine where the source of the BOM or pollutants comes from. For instance, a low DO (anaerobic conditions) can results in fish death in a water body. The normal DO content of water is approximately 8 milligrammes per litre (mg/l) to $9 \mathrm{mg} / \mathrm{l}$ and at below $5 \mathrm{mg} / \mathrm{l}$ aquatic life will be affected (ibid.).

A high level of BOD would indicate an elevated level of organic substrate for subsequent microbial growth that could result in depletion of DO in the water and that may cause biofouling of distribution systems and rapid degradation of water quality (ibid.). As BOD is a general indicator of water quality, it is best used in conjunction with other factors such as total or faecal coliforms levels specific nutrients, lead, DO, and COD. BOD and COD are better determinants of organic substrates than DO (ibid.). So, the total suspended solids (TSS) and the high turbidity can interfere with the disinfection treatment and thus reduce the effectiveness of disinfection; they are important parameters to monitor. For instance, inorganic and organic colloids may protect microorganisms from the chemical action of chlorine or ultraviolet radiation (UV) disinfection (ibid.).

Thus, the treatment required will be different and will be in accordance with the reuse intent [60]. The treatment needed represented graphically in Fig. 6, is dictated by the end application of the recycled water for achieving economic efficiency and environmental sustainability [22]. Only the treatment train or subset of method illustrated at Fig. 6 will be used for the selected source of non-potable water and the quality required for its intended use. For instance, screening is only necessary for rainwater reuse to prevent debris and contaminants from the roof to enter the water system [60], which is not the case of the $\mathrm{A} / \mathrm{C}$ condensate water or the reverse osmosis reject water (RORW).

The United States Environment Protection Agency [22] Guidelines for Water Reuse recommends water quality threshold and monitoring practices for recycled water for specific water application categories as provided in Table 2, which are equivalent to the Regulatory and Supervision Bureau [14] requirements.

The MFCS non-potable water reuse is classified as unrestricted reuse [14] because there are no fences separating public access to the WFs and a sprinkler system is used for the grass area on top of a drip irrigation system for the plants and trees. Thus, the level of treatment will follow the recommendations outlined in Table 2. United States Environment Protection Agency [22] recommends achieving the protection of public health by firstly reducing or eliminating concentrations of pathogenic bacteria, parasites, and enteric viruses in recycled water; secondly controlling chemical constituents in recycled water; and thirdly limiting public exposure (contact, inhalation, or ingestion) to recycled water. Recycled water projects will vary significantly in the level of human exposure incurred, with a corresponding variation in the potential for health risks. As illustrated in Appendix Fig. 11, where human exposure is likely, recycled water should be treated to a high degree prior to its use.

To make reuse cost-effective, the level of treatment must be "fit for purpose". Secondary effluent can become recycled water reuse by addition of filtration and enhanced disinfection. Higher level uses (for example potable reuse) may include additional processes, such as advanced oxidation process to remove chemical and biological constituents [22].

\section{Test Result Evaluation Criteria}

The Substances measured in the water as per RSB $[14,64])$ requirements and Duncan et al. [15] recommendations for recycled water and for drinking water are listed in Appendix Table 9. The water test results will be evaluated against these parameters.

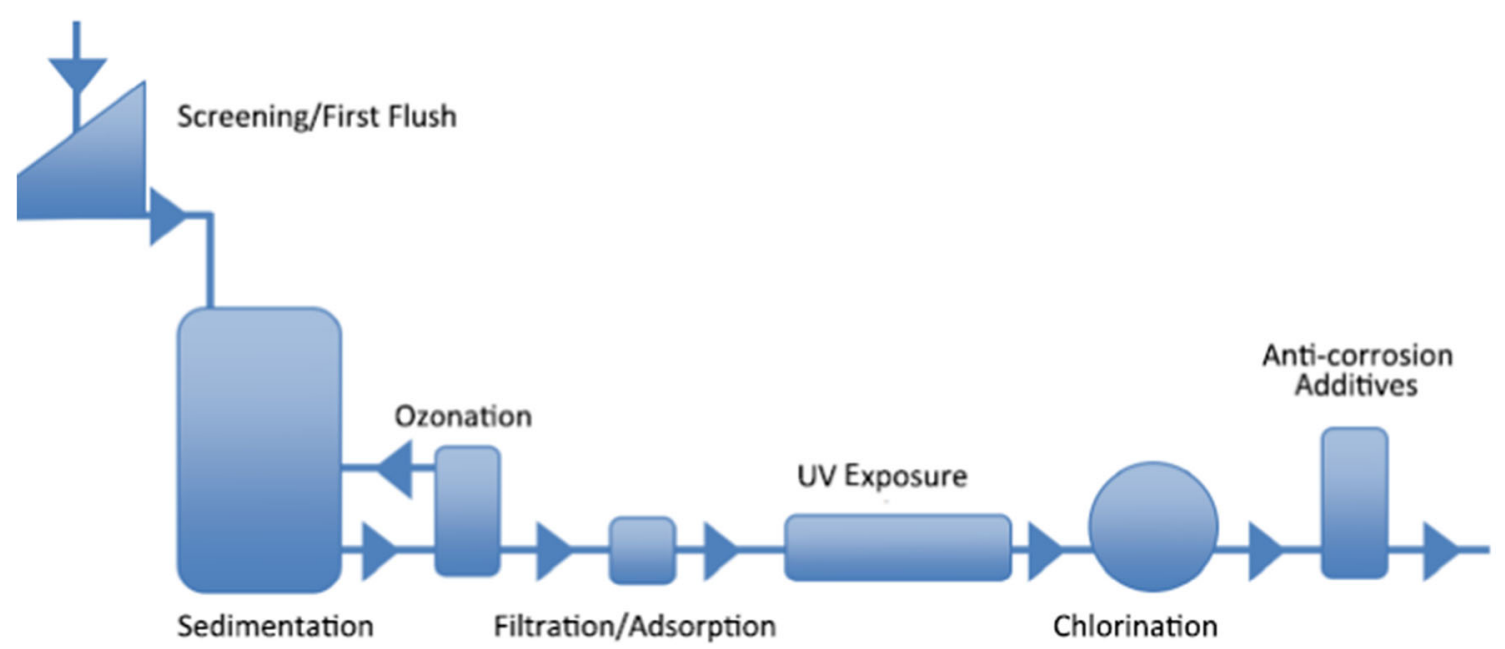

Fig. 6 Schematic of a treatment train including all traditional treatment methods ([60], p.16) 
Table 2 Recycled Water level of treatment for Unrestricted Reuse ([22], p. 6-2)

\begin{tabular}{|c|c|c|c|}
\hline Reuse category and description & Treatment & Reclaimed water quality & Reclaimed water monitoring \\
\hline $\begin{array}{l}\text { The use of reclaimed water in } \\
\text { non-potable applications in } \\
\text { municipal settings where public } \\
\text { access is not restricted. }\end{array}$ & $\begin{array}{l}\text { - Secondary } \\
\text { - Filtration } \\
\text { - Disinfection }\end{array}$ & $\begin{array}{l}\text { - } \mathrm{pH}=6.0-9.0 \\
\leq 10 \mathrm{mg} / \mathrm{l} \text { BOD; } \\
\leq 2 \mathrm{NTU} \\
\text { - No detectable faecal coliform per } 100 \mathrm{ml} \\
\text { - } 1 \mathrm{mg} / 1 \text { chloride residual (min.) }\end{array}$ & $\begin{array}{l}\text { - } \mathrm{pH}-\text { weekly; } \\
\text { - BOD_weekly; } \\
\text { - Turbidity: continuous } \\
\text { - Faecal coliform: daily; } \\
\text { - Chloride residual: continuous. }\end{array}$ \\
\hline
\end{tabular}

\section{Non-potable Water Reuse Risk Management}

Figure 7 classifies non-potable water types according to the Victorian Government Department of Health [63] water hierarchy and provides health risks associated with these water types for reuse and recycling based on the Victorian Government Department of Health [63] recommendations. Yet, this risk assessment only considers human health impact; it does not address issues such as physio-chemical contaminants causing scaling or corrosion of fixtures/fittings or contaminants that may affect the environment if water is used for LI or for WFs.

\section{Results}

\section{Non-potable Water Standard Characterization}

The Recycled Water and Biosolids Regulation 2010 [14] addresses maximum concentration values for Microbiology, inorganic (trace elements), and sanitary water quality criteria. Physical, salinity, and organic (pesticides and others) criteria are specified in the Water Quality Regulation [64], which addresses potable water quality criteria. However, these standards do not recommend concentration limits for LI salinity and toxicity.

Yet, as recommended by Duncan et al. [15] and Landschoot [65], the four factors that are critical for consideration in water LI quality are total salt content (total dissolved solids (TDS) and electrical conductivity (EC)), sodium permeability hazard specific sodium absorption ratio (SAR), adjusted SAR and residual sodium carbonate, ion toxicity (sodium, chloride, boron, bicarbonate, and $\mathrm{pH}$ ), and critical nutrient levels (phosphorous, phosphate, potassium, calcium, magnesium, nitrogen, nitrate, sulphur, and sulphate). For instance, the RSB [14, 64]) does not provide electrical conductivity and sodium absorption ratio (SAR) concentration limits. The latter parameters measure the relative concentration of sodium to calcium and magnesium $[15,19]$. Mainly and in most cases in the literature, $\mathrm{A} / \mathrm{C}$ condensate water reuse is essentially addressed in terms of quantity [66-69]. Plus, little is thoroughly discussed about non-potable water quality for reuse and specifically its effect on soil and plants or its corrosive effect on irrigation canal linings [70-72].

\section{Non-potable Water Classification}

ASHRAE. American Society of Heating, Refrigerating and Air-Conditioning Engineers [73] and the Green Plumbing and Mechanical Code Supplement (GPMCS) classify A/C condensate under the category of alternative on-site sources of water and on-site treated non-potable water respectively. ASHRAE Standard 191, Standard for the Efficient Use of Water in Building Mechanical Systems is currently under review and is not yet published [74]. It will include a variety of non-potable water sources, which is to date not addressed in any ASHRAE standards.

More information on the available standards for nonpotable water sources of water is summarized in Appendix Table 10.

The role of the RSB is assuring safe and efficient electricity, water, and wastewater services. The bureau defines wastewater as the "water-borne wastes generated by any domestic, commercial or industrial activity including Grey Water and Trade Effluent" ([14], p.11), and it defines Reuse as the "release to the environment or recycling of Recycled Water and Biosolids for the benefit of the environment" or the public ([14], p.10). Thus, A/C condensate water falls within the definition of the bureau because it is generated from a commercial activity. Yet, classifying the above type of non-potable
Fig. 7 The risk hierarchy for nonpotable water recycling ([63], p. 6)
Lowest risk Highest risk

\begin{tabular}{|l|c|c|c|}
\hline RAINWATER & $\begin{array}{c}\text { PROCESS } \\
\text { WATER }\end{array}$ & STORMWATER & GREYWATER SEWAGE \\
\hline
\end{tabular}


water as a single class of non-potable water or wastewater lacks precision in terms of water characterization and classification if compared with the American Water Works Association (AWWA) definitions for each type and other international codes and standards such as the San Antonio Plumbing Code (SAPC) [51], Texas Commission on Environmental Quality [52, 53], ASHRAE. American Society of Heating, Refrigerating and Air-Conditioning Engineers [73], and the Green Plumbing and Mechanical Code Supplement (GPMCS) [54] as described in Appendix Table 11.

Condensate water is generated in the same way as distilled water. Thus, it can be classified as such [60, 50]. Condensate water's particularity is that it contains no minerals and it has a slightly acidic $\mathrm{pH}$ (around 5.8) ([78] cited in [60]) due to its reaction to contact with metals such as cooling coils, drain pans, pipes, valves, meters, and tanks [60]. Yet, AHU A/C condensate water would be different in nature than food waste effluent for instance because the water content varies according to the water source input [59].

\section{Non-potable Water Test Results}

\section{CS2 PP3 Results}

The Case Study 2 (CS2) Pilot Empirical Study 3 (PP3), A/C Condensate Water Quality Testing laboratory water test reports conducted in May 2016 have been analysed by the author and compared to establish how the water quality has impacted water savings, health and growth of the vegetation. In May 2016, the laboratory condensate water test results provided evidence that:

- All parameters (sanitary, physical, microbiology) of the raw and treated condensate water tested met Regulatory and Supervision Bureau [14] requirements.
- The condensate water sanitary parameters were remarkably similar to the municipality desalinated water.

- The TDS levels of the municipality desalinated water were slightly higher than the treated condensate water.

- The condensate water TDS, SAR, and ECw were exceptionally low, which meant condensate water has the same characteristics as ultrapure water, also called low-salinity water and low electrolyte water [15].

As summarized in Table 3, the condensate water had a low electrical conductivity $(\mathrm{ECw}<0.2 \mathrm{dS} / \mathrm{m})$ and a $\mathrm{pH}$ outside the normal range because this water type has a very low buffering capacity, which can cause few problems for soil including infiltration rate because of the ion imbalance, but also will rapidly corrode pipelines, sprinklers, and control equipment $[15,18]$. Table 3 offers a summary of the condensate water tested for $\mathrm{pH}$ in 2016, which shows its variation through the treatment channel. The $\mathrm{pH}$ was higher at the treated water tank than at the raw water tank, which provides evidence that the limestone contactor (secondary treatment) was effective at regulating the $\mathrm{pH}$.

\section{CS2 Intervention 3 Results: AHU A/C Condensate Water}

This section presents results of the AHU A/C condensate water tested, as undertaken by an independent certified Emirates Authority for Standardization and Methodology (ESMA) laboratory. The water has been evaluated against the maximum allowable concentration or characteristic of Restricted Substances as specified in Schedule A1 and A2 of the RSB for the Recycled Water and Biosolids Regulations 2010 [14] in addition to concentration limits as tabulated in Appendix Table 9.

The condensate water was sampled, tested, and analysed in March 2017. Table 4 tabulates the sanitary and salinity main parameters' results. The laboratory test

Table 3 CS1 PP3 condensate water test summary

\begin{tabular}{|c|c|c|c|}
\hline Condensate water testing results in 2016 & $\mathrm{pH}$ & SAR $(\mathrm{meq} / \mathrm{l})$ & $\mathrm{ECw}(\mathrm{ds} / \mathrm{m})$ \\
\hline T51-1 raw condensate water tank (May 2016) & 7.6 & 0.85 & 0.17 \\
\hline T51-1 raw condensate water tank (July 2016) & 6.8 & 0 & 0.04 \\
\hline T51-2 raw condensate water tank (July 2016) & 7.0 & 0.07 & 0.03 \\
\hline T42-1 treated condensate water tank (secondary treatment) (May 2016) & 7.7 & 0.45 & 0.12 \\
\hline T42-1 treated condensate water tank (secondary treatment) (July 2016) & 8.1 & 0.12 & 0.03 \\
\hline T52-1 treated WF water tank (secondary treatment) (July 2016) & 7.9 & 0.03 & 0.13 \\
\hline Municipality desalinated water (May 2016) & 7.7 & 0.64 & 0.13 \\
\hline Regulatory and Supervision Bureau [14] recommended values for water recycling & 6 to 8 & - & - \\
\hline Duncan et al. [15] recommended values & 6.5 to 8.4 & 5.7 & 1.5 \\
\hline United States Environment Protection Agency [22] recommended values & 6 to 9 & - & - \\
\hline
\end{tabular}


Table 4 CS2 Intervention 3 condensate water sanitary and salinity testing results (2017)

\begin{tabular}{|c|c|c|c|c|c|c|c|}
\hline Water tested by location & $\mathrm{pH}$ & $\mathrm{BOD}(\mathrm{mg} / \mathrm{l})$ & $\mathrm{DO}(\mathrm{mg} / \mathrm{l})$ & TSS (mg/l) & TDS (mg/l) & SAR (meq/l) & $\mathrm{ECw}(\mathrm{ds} / \mathrm{m})$ \\
\hline \multicolumn{8}{|l|}{7 March 2017} \\
\hline T51-1 raw condensate water tank & 7.05 & $<3$ & 6.2 & $<6$ & 40 & 0.40 & 0.06 \\
\hline T51-2 raw condensate water tank & 6.8 & $<3$ & 6.2 & $<6$ & 30 & 0.75 & 0.05 \\
\hline T42-1 treated condensate water tank & 7.62 & $<3$ & 6.1 & $<6$ & 56 & 0.53 & 0.09 \\
\hline T52-1 treated WF water tank (secondary treatment) & 7.9 & $<3$ & 6.2 & $<6$ & 76 & 0.83 & 0.13 \\
\hline Treated desalinated water (May 2016) & 7.7 & $<3$ & 6.2 & $<6$ & 78 & 0.64 & 0.13 \\
\hline $\begin{array}{l}\text { Regulatory and Supervision Bureau [14] recommended } \\
\text { values for water recycling }\end{array}$ & 6 to 8 & $<10$ & $\geq 1$ & $<10$ & - & & - \\
\hline Duncan et al. [15] recommended values & 6 to 8 & - & - & - & $<960$ & $<6$ & $>0.7$ \\
\hline $\begin{array}{l}\text { United States Environment Protection Agency [22] } \\
\text { recommended values }\end{array}$ & 6 to 9 & $<10$ & - & - & - & & \\
\hline
\end{tabular}

results provide evidence that the sanitary parameters meet Regulatory and Supervision Bureau [14] requirements. The test results also demonstrate that the condensate water quality is very similar to the treated desalinated water, except for the TDS level, which is higher than the treated condensate water. However, the salinity levels for both the condensate and the desalinated water such as SAR and ECw are much lower than the recommended concentration limits, which is characteristics of ultra-low electrolyte water type.

The microbiology results (see Table 5) provide evidence that the parameters meet Regulatory and Supervision Bureau [14] requirements. Other microbiology parameters tested in colony-forming unit (CFU/l), and not tabulated below were helminth ova and Legionella, which were non-detectable. And Escherichia coli (E. coli) and faecal streptococci were less than one $(<1)$.

The heterotrophic plate count (HPC) provides evidence that microorganisms are present in the raw condensate water, but below the World Health Organization [79] concentration limits. Microorganisms occur naturally in water as a normal part of the microbiota of water, and microorganisms recovered through HPC tests generally include those, which may include organisms derived from diverse pollutant sources (ibid.). Increase of HPC does not indicate the existence of a health risk if the water meets acceptable microbial water quality norms [80]. That is the reason why the HPC measurement alone is unsuitable for use and faecal indicator bacteria, such as E. coli, faecal coliforms, and Pseudomonas aeruginosa measurement is essential [79]. A high count of bacteria may indicate the need for disinfection (ibid.). However, there is no evidence that HPC has a direct relationship to the presence of regrowth organism, such as Legionella, $P$. aeruginosa, and non-tuberculous mycobacteria (ibid.).

\section{Non-potable Water Treatment Risk Assessment Results}

A summary of CS2 intervention results is given at the MFCS if a full implementation of the methods discussed above is undertaken.

Table 5 CS2 Intervention 3 condensate water microbiology testing results (2017)

\begin{tabular}{llll}
\hline Condensate water tested by location 7 March 2017 & $\begin{array}{l}\text { Total coliforms } \\
(\mathrm{CFU} / 100 \mathrm{ml})\end{array}$ & $\begin{array}{l}\text { Total bacterial count (heterotrophic } \\
\text { plate count) (CFU/100 ml) }\end{array}$ & $\begin{array}{l}\text { Pseudomonas aeruginosa } \\
\text { (CFU/100 ml) }\end{array}$ \\
\hline T51-1 raw condensate water tank & $<1$ & 96 & Non-detectable \\
T51-2 raw condensate water tank & $<1$ & 250 & Non-detectable \\
T42-1 treated condensate water tank & $<1$ & $<1$ & Non-detectable \\
$\begin{array}{l}\text { T52-1 raw WF water tank } \\
\begin{array}{l}\text { Regulatory and Supervision Bureau [14] } \\
\text { recommended values for water recycling }\end{array}\end{array}$ & $<1$ & 34 & Non-detectable \\
$\begin{array}{l}\text { United States Environment Protection Agency [22] } \\
\text { recommended values }\end{array}$ & Non-detectable & - & $<1$ \\
\begin{tabular}{l} 
World Health Organization [79] \\
\hline
\end{tabular} & - & $<500$ & - \\
\hline
\end{tabular}


Fig. 8 The risk hierarchy for AHU A/C condensate water recycling at the MFCS adapted from [63], p. 6)

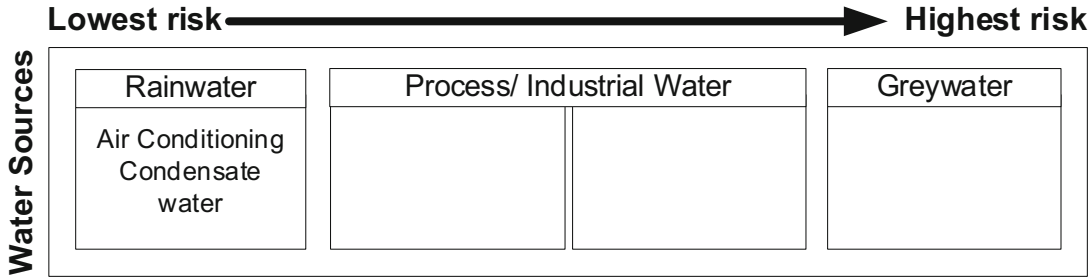

Figure 8 classified the MFCS AHU A/C condensate water according to the Victorian Government Department of Health [63] water hierarchy. This provides health risks associated with this water type for reuse and recycling based on the Victorian Government Department of Health [63] recommendations in terms of human health impact.

As observed by Duncan et al. [15], rainwater is classified as an electrolyte or pure water. And as evidenced by the authors, AHU A/C condensate water has the same characteristic than rainwater, which means that in terms of human health impact $\mathrm{AHU} \mathrm{A} / \mathrm{C}$ condensate water can be classified as rainwater as shown in Fig. 8.

Tailoring water treatment to a specific purpose ("fit for purpose") for public health and environmental protection is advised by United States Environment Protection Agency [22] and the International Green Construction Code [53, 60] for two reasons: firstly, to minimize the cost of operation and maintenance and, secondly, to ensure the health risk factor is minimized [22].

As shown in Table 6, secondary and tertiary (filtration and disinfection) water treatment will be necessary for $\mathrm{A} / \mathrm{C}$ condensate water for LI and WFs use to minimize human exposure to risks of viral or bacterial contamination. This holds specifically true for the sprinkler irrigation and the WFs, whose spray could firstly contaminate patients and/or visitors and secondly run-off to the nearby sea, and thus contaminate the environment if water was untreated. Whilst secondary treated wastewater can be reused for irrigation, tertiary treatment is recommended for unrestricted irrigation use [14, 22, 81].

Another possibility would be the reuse of AHU A/C condensate water for toilet flushing. However, because the building typology is a hospital, the quality would need to be stringent for indoor reuse $[61,62,82]$. Thus, a more advanced treatment system would be needed. Besides it is not clear if the $\mathrm{AD}$ regulations permit recycled water reuse for toilet flushing in commercial buildings and more specifically in hospitals. Indeed, this option does not form part of the MFCS design intent and so is excluded from this research.

Referring to Fig. 9, in 2016 the raw condensate water from the HVAC system was collected in two raw condensate storage tanks (T51-1 and T51-2) located at level P3. The treatment system downstream of tanks T51-1 and T51-2 was designed to treat $\mathrm{AHU} \mathrm{A} / \mathrm{C}$ condensate water through primary and secondary treatment.

The condensate water circulates through the existing limestone contactor, which dissolves calcium carbonate (limestone) in water, which increases the alkalinity of the water (between 7.5 and 8), and in turn helps reduce the corrosion of lead and copper [77]. This was clearly observed when the water was analysed $[8,11]$.

The existing ozone/chlorine combined disinfection treatment system function is to treat the water for WF's use to a level required by Regulatory and Supervision Bureau [14]. The particularity of the ozone is that it cannot be stored on-site and it must be generated on-site as needed and it is only sparingly soluble in water. Because ozone has a very short life, it needs to be efficiently introduced into the water to be successfully treating it. Ozone is toxic and highly corrosive, and it must be used with allowable limits set by Occupational Safety and Health Administration (OSHA) [77].

Table 6 CS2 Intervention 3 potential non-potable water reuse evaluation

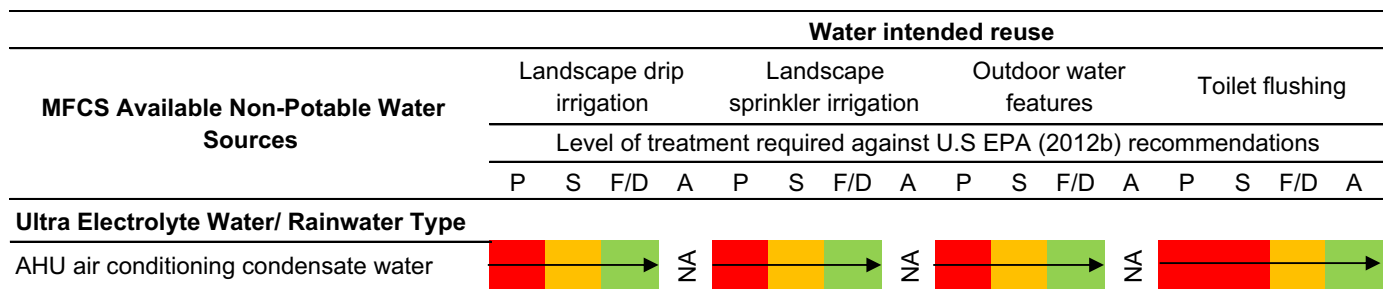

$P$, primary; $S$, secondary; $F / D$, filtration/disinfection; $A$, advanced; $N A$, not applicable. Risk of human exposure: low risk 


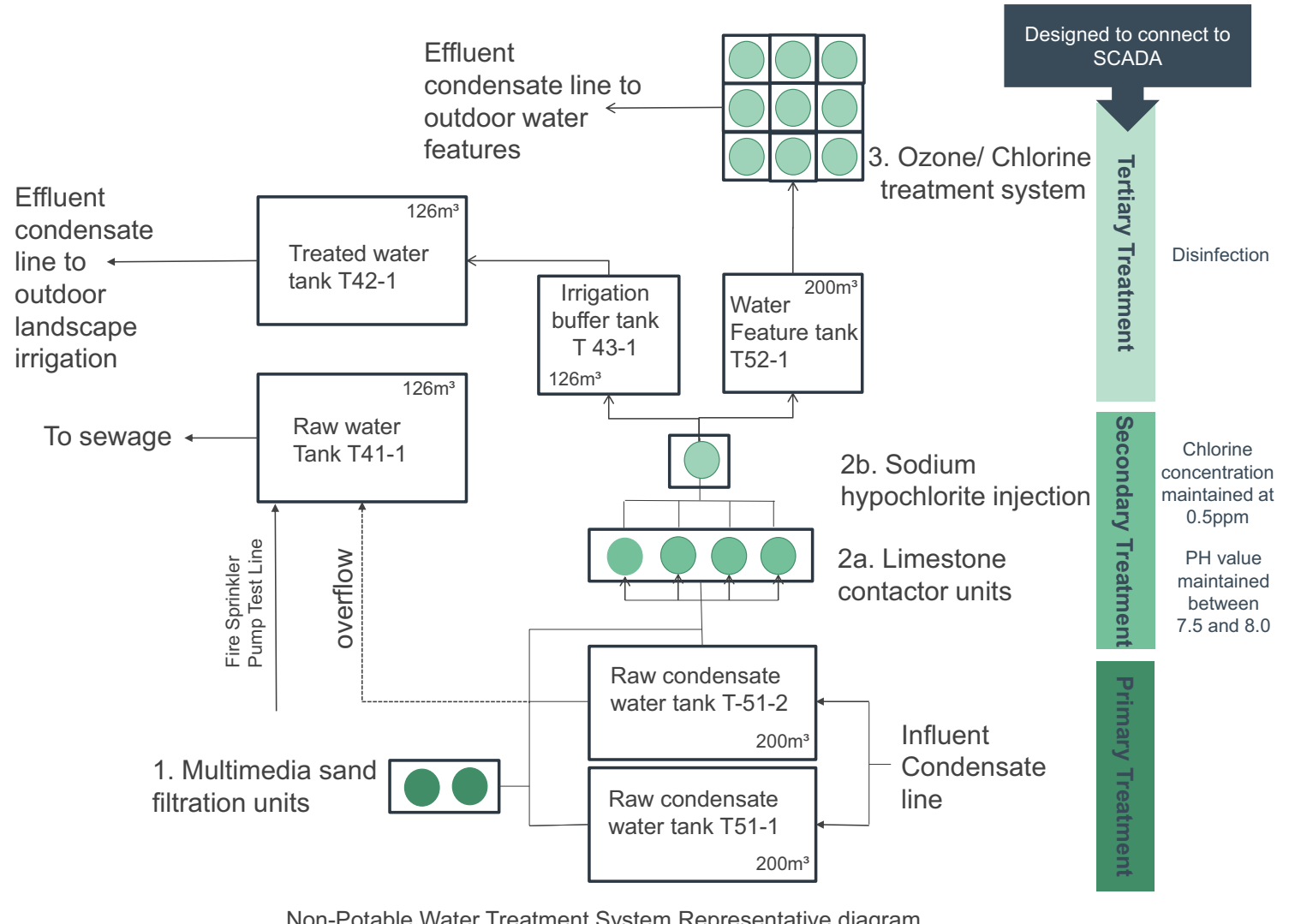

Non-Potable Water Treatment System Representative diagram

Fig. 9 CS2 Intervention 3 non-potable water treatment system configuration in 2016 (updated from [8], p. 557)

\section{Discussion}

\section{Contributions from the Non-potable Water Quality Assessment Methodology}

The CS2 (Water Quality) PP3 and Intervention 3 (A/C Condensate Water Testing and Analysis) were initiated by the author in May 2016 and June 2017 to classify and characterize $\mathrm{A} / \mathrm{C}$ condensate water at the MFCS to understand its impact on the LI, human health, and the building water systems. The findings were that the Regulatory and Supervision Bureau [14] standard does not address this water type for reuse nor does it address its salinity and toxicity concentration limits.

It was found that $\mathrm{A} / \mathrm{C}$ condensate water requires tertiary treatment for unrestricted reuse because bacterial counts are still present prior to secondary treatment. This point contradicts Cabrera [71] for example who stated that "condensate water required minimal treatment". More, Glawe [60], Loveless et al. [69], Bryant and Ahmed [70], Kant et al. [72], Ali Khan and AlZubaidy [66], and United States Environment Protection Agency [22] are mainly addressing nonpotable water quantities and/or microbiological treatment. None of these authors has addressed the application of non-potable water such as condensate water for LI and WF use and their effect on soil, nor their energy and environmental impact on the cited end use on a long term.

The RSB $[14,64])$ does not provide electrical conductivity and sodium absorption ratio (SAR) concentration limits. The latter parameters measure the relative concentration of sodium to calcium and magnesium $[15,19]$. Mainly and in most cases in the literature, $\mathrm{A} / \mathrm{C}$ condensate water reuse is essentially addressed in terms of quantity (Loveless et al. 2012; [66-68]). Plus, little is thoroughly discussed about non-potable water quality for reuse and specifically its effect on soil and plants or its corrosive effect on irrigation canal linings [70-72].

\section{Water Quality Assessment in Relation to Soil Quality}

The U.S Salinity Laboratory at Riverside California (1947) [15] classified rainwater as ultrapure low electrolyte water because it is extremely low in dissolved salt content, which causes soil infiltration rate problems independently of the soil sodium content measured as sodium 
Table 7 Non-potable water quality key considerations summary

Non-potable water types for reuse for LI and WFs
Key issues to consider (see Tables 6 and 9 for non-potable water reuse recommendation limits and quality risk assessment)
Impact

\begin{tabular}{llll}
\hline Soil & Pipe & Soil & Human \\
infiltration & corrosion & pollution & health
\end{tabular}

X $\quad \mathrm{X}$

absorption ratio (SARw) (Christiansen, 1947 in [15]). Thus, condensate water has similar characteristics to rainwater. When this water type, such as condensate water, is tested and found with a SARw between nil and three and with an electrical conductivity (ECw) below 0.2 , it is classified under severe restriction and it should be managed by high level management skilled professionals such as experienced LI managers [16]. The characteristic of ultrapure water is its ability to leach sodium and potassium more than calcium and magnesium $[15,16,83]$. The water purity in terms of salt concentrations is solely identified by its electrical conductivity level criteria regardless of the SARw $[15,16]$.

\section{Target Audience}

The original and significant contribution to change in professional practice and knowledge will be most useful to building and estate owners, facility managers, and landscape contractors who are responsible for using air conditioning condensate water against desalinated potable water and minimizing costs and GHG emissions during operations.

Table 7 provides a summary of the key issues that need to be addressed by the audience target when reusing $\mathrm{A} / \mathrm{C}$ condensate water for LI and WFs at unrestricted level.

\section{Recommendations and Key Considerations}

The following recommendations from the authors are therefore to encourage the local authority to first classify air conditioning condensate water under the same category as rainwater rather than the single denomination of wastewater because both these water types have the same characterization. The level of water treatment for $\mathrm{AHU} \mathrm{A} / \mathrm{C}$ condensate water will include secondary and filtration/disinfection for unrestricted reuse to minimize the risk of faecal bacterial counts and to ensure that EC and SARw levels are sufficient to prevent piping corrosion and soil rate infiltration problems. Second is to develop a sustainable water conservation and reuse strategy (SWC) forming the basis for a water protocol including an assessment methodology to measure the impact of non-clinical non-potable water on soil and building hydraulic system as summarized in Fig. 10.

The findings for assessing nonclinical non-potable water for outdoor reuse in a decentralized system can be summarized as follows:

a Estimate the quantity of non-potable water generated onsite.

b Identify an end use according to the quantity that can be generated.

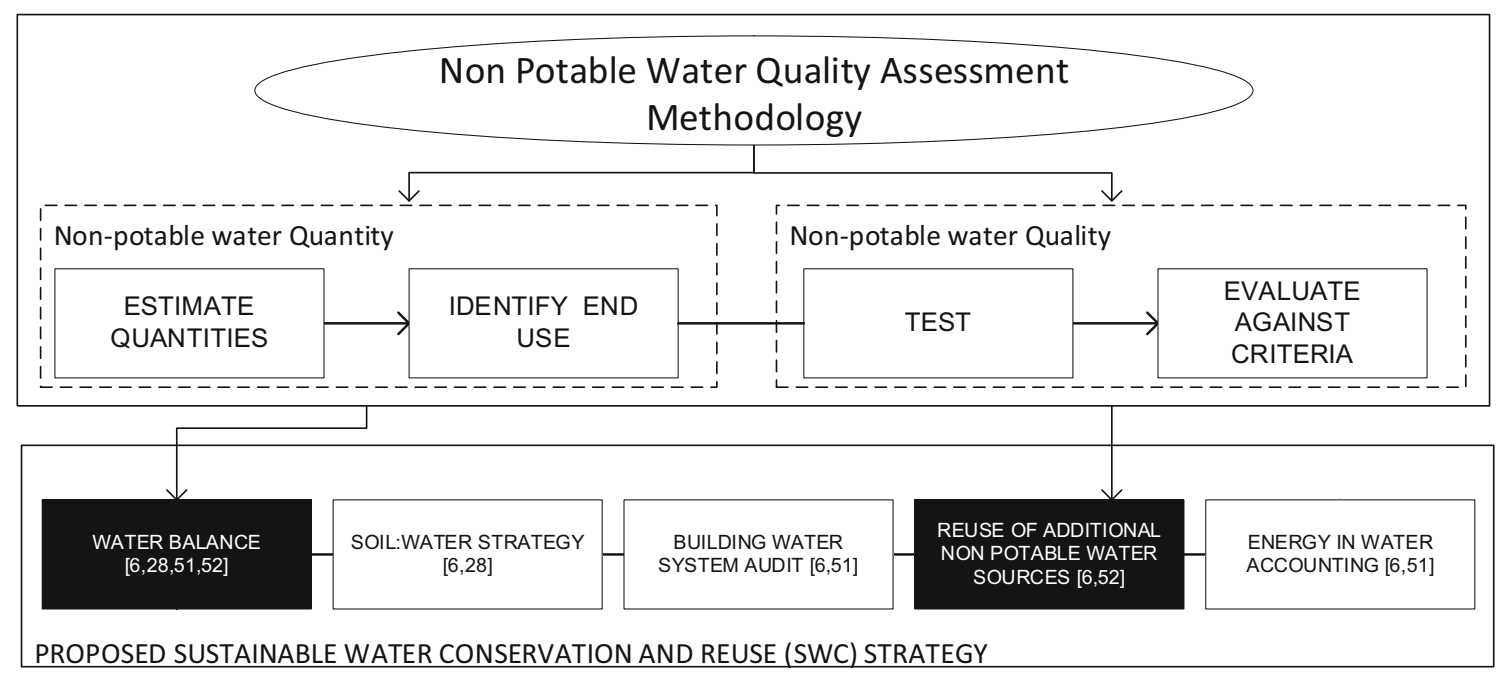

Fig. 10 Summary of the water conservation protocol for a decentralized system adapted from [10] 
Table 8 Essential criteria of evaluation for AHU A/C condensate water reuse

\begin{tabular}{llllllll}
\hline Criteria of evaluation & SARw (meq/l) & EC (ds/m) & TDS (mg/l) & Sodium (mg/l) & Chloride (mg/l) & Boron (mg/l) & Bicarbonate (mg/l) \\
\hline $\begin{array}{l}\text { Toxicity } \\
\text { Salinity }\end{array}$ & $\mathrm{X}$ & $\mathrm{X}$ & $\mathrm{X}$ & $\mathrm{X}$ & $\mathrm{X}$ & $\mathrm{X}$ & $\mathrm{X}$ \\
\hline
\end{tabular}

The boundary for water reuse in this research extends to landscape irrigation and water features.

c Test the selected non-potable water generated on-site for SARw, EC, toxicity, and microbiology (the latter specifically for healthcare).

d Classify the non-potable water type selected under either ultra-electrolyte water, process/industrial, or greywater type. According to the test results, evaluate the water against the criteria of toxicity, salinity (Table 8), and microbiology [14].

In addition to addressing the Regulatory and Supervision Bureau [14] maximum concentration limits, which includes potassium, for non-potable water reuse, the water quality parameters shown in Table 8 should be tested against Appendix Table 9 water recycling concentration limits.

\section{Conclusions}

This paper presented a MFCS in AD and the existing treated non-potable water system for LI and WF use has been discussed, including a water supply strategy based on an action research methodology for minimizing the use of both desalinated water and non-potable water for LI and WFs to alleviate water stress in AD. The results of CS2 (Water Quality) CS2 PP3, Pilot Empirical Study 3 (2016 AHU A/C Condensate Water Quality Testing and Analysis) and CS2 Intervention 3 (2017 AHU A/C Condensate Water Quality Testing and Analysis) were discussed, which focused on assessing the impact of AHU A/C condensate water quality on soil and building systems.

The findings have led to a non-potable water quality assessment methodology as part of a proposed sustainable water strategy in the UAE to evaluate non-potable water quality for LI and WF reuse. The AHU A/C condensate water test results have first provided evidence that this type of non-potable water has the characteristic of ultrapure water and thus it is classified under severe restriction alike rainwater for having an exceptionally low EC and SARw. The AHU A/C condensate water low dissolved salt content characteristic is its ability to leach soil minerals and hence causes infiltration problem and if not treated can become a cause for water wastage. The test results have also shown that microorganisms were present in the raw condensate water, but below the concentration limits and that faecal indicator bacteria testing suffice to monitor health risks.

The water supply strategy can be extended to any commercial building design in $\mathrm{AD}$ because most buildings are equipped with an $\mathrm{AHU} \mathrm{A} / \mathrm{C}$ condensate water system. To minimize the use of desalinated water and minimize the impact on the environment, the following changes in practice are required.

- Buildings designed with an AHU A/C condensate water with a cooling load equal or greater than $350 \mathrm{~kW}$ should collect, store, and treat ("fit for purpose") condensate water for reuse for either LI and/or outdoor WFs use including toilet flushing subject for the latter to have an advanced treatment system.

- For LI and WF unrestricted reuse, the AHU AC condensate water parameters for toxicity and salinity should be tested and analysed - in addition to microbiology parameters for human health purpose - to mainly reduce soil infiltration problems and consequently conserve water and associated energy, and to protect building hydraulic systems against corrosion.

- Non-potable water treatment system should be selected "fit for purpose" to guarantee human safety, protect the environment, and maximize operational cost.

- The non-potable water should be managed by an experienced water professional accredited water treatment operator.

The next steps are to first confirm if the soil rate infiltration at the MFCS is affected by the AHU A/C condensate water quality or other factors, and second to assess and publish the results of additional non-potable water quality such as food waste effluent, fire protection services test water, and reverse osmosis reject water, which are being developed for another paper. 


\section{Appendix}

\begin{tabular}{|c|c|c|c|c|}
\hline \multirow{2}{*}{$\begin{array}{l}\text { Treatment } \\
\text { Level }\end{array}$} & \multicolumn{3}{|c|}{ Increasing Levels of Treatment } & \multirow[b]{2}{*}{ Advanced } \\
\hline & Primary & Secondary & $\begin{array}{l}\text { Filtration and } \\
\text { Disinfection }\end{array}$ & \\
\hline Processes & Sedimentation & $\begin{array}{l}\text { Biological oxidation } \\
\text { and disinfection }\end{array}$ & $\begin{array}{l}\text { Chemical } \\
\text { coagulation, } \\
\text { biological or } \\
\text { chemical nutrient } \\
\text { removal, filtration, } \\
\text { and disinfection }\end{array}$ & $\begin{array}{l}\text { Activated carbon, } \\
\text { reverse osmosis, } \\
\text { advanced oxidation } \\
\text { processes, soil } \\
\text { aquifer treatment, } \\
\text { etc. }\end{array}$ \\
\hline \multirow{5}{*}{ End Use } & \multirow{5}{*}{$\begin{array}{l}\text { No uses } \\
\text { recommended }\end{array}$} & $\begin{array}{l}\text { Surface irrigation of } \\
\text { orchards and } \\
\text { vineyards }\end{array}$ & $\begin{array}{l}\text { Landscape and golf } \\
\text { course irrigation }\end{array}$ & \multirow{5}{*}{$\begin{array}{l}\text { Indirect potable } \\
\text { reuse including } \\
\text { groundwater } \\
\text { recharge of potable } \\
\text { aquifer and surface } \\
\text { water reservoir } \\
\text { augmentation and } \\
\text { potable reuse }\end{array}$} \\
\hline & & $\begin{array}{l}\text { Non-food crop } \\
\text { irrigation }\end{array}$ & Toilet flushing & \\
\hline & & $\begin{array}{l}\text { Restricted landscape } \\
\text { impoundments }\end{array}$ & Vehicle washing & \\
\hline & & $\begin{array}{l}\text { Groundwater } \\
\text { recharge of } \\
\text { nonportable aquifer }\end{array}$ & Food crop irrigation & \\
\hline & & $\begin{array}{l}\text { Wetlands, wildlife } \\
\text { habitat, stream } \\
\text { augmentation }\end{array}$ & $\begin{array}{l}\text { Unrestricted } \\
\text { recreational } \\
\text { impoundment }\end{array}$ & \\
\hline & & $\begin{array}{l}\text { Industrial cooling } \\
\text { processes }\end{array}$ & Industrial systems & \\
\hline Human Exposure & \multicolumn{4}{|c|}{ Increasing Acceptable Levels of Human Exposure } \\
\hline Cost & \multicolumn{4}{|c|}{ Increasing Levels of Cost } \\
\hline
\end{tabular}

Fig. 11 Type of water reuse appropriate for increasing levels of treatment ([84], p. 6-2) 
Table 9 CS2 Intervention 3 non-potable water evaluation: updated water recycling recommendation limits

\begin{tabular}{|c|c|c|c|c|c|c|}
\hline \multicolumn{7}{|c|}{ Nutrient guidelines in irrigation water (mg/l), Duncan et al. [15] } \\
\hline Nutrient parameters & Symbol & Units & Low & Normal & High & Very high \\
\hline Sulphur & S & $\mathrm{mg} / 1$ & $<10$ & & $30-60$ & $>60$ \\
\hline Sulphate & & $\mathrm{mg} / 1$ & $<30$ & $30-90$ & $90-180$ & $>180$ \\
\hline Nitrate & & $\mathrm{mg} / 1$ & $<5$ & & $50-100$ & $>100$ \\
\hline Calcium & $\mathrm{Ca}$ & $\mathrm{mg} / \mathrm{l}$ & $<20$ & $20-60$ & $60-80$ & $>80$ \\
\hline Magnesium & $\mathrm{Mg}$ & $\mathrm{mg} / 1$ & $<10$ & & $25-35$ & $>35$ \\
\hline Potassium & $\mathrm{K}$ & $\mathrm{mg} / 1$ & $<5$ & & $20-30$ & $>30$ \\
\hline Nitrogen & $\mathrm{N}$ & $\mathrm{mg} / \mathrm{l}$ & $<1.1$ & $1.1-11.3$ & $11.3-22.6$ & $>22.6$ \\
\hline Phosphorous & $\mathrm{P}$ & $\mathrm{mg} / \mathrm{l}$ & $<0.01$ & $0.1-0.4$ & $0.4-0.8$ & $>0.8$ \\
\hline \multicolumn{7}{|c|}{ Reclaimed water guidelines (mg/l), Duncan et al. [15] } \\
\hline Salinity parameters & Symbol & Units & \multicolumn{4}{|c|}{ Recommended maximum values } \\
\hline Electrical conductivity & EC & $\mathrm{ds} / \mathrm{m}$ & \multicolumn{4}{|c|}{1.5} \\
\hline Sodium & $\mathrm{Na}$ & $\mathrm{mg} / \mathrm{l}$ & \multicolumn{4}{|l|}{200} \\
\hline Chloride & $\mathrm{Cl}$ & $\mathrm{mg} / 1$ & \multicolumn{4}{|l|}{250} \\
\hline Boron & B & $\mathrm{mg} / 1$ & \multicolumn{4}{|l|}{0.5} \\
\hline Bicarbonate & & $\mathrm{mg} / \mathrm{l}$ & \multicolumn{4}{|l|}{250} \\
\hline Total dissolved solids & TDS & $\mathrm{mg} / \mathrm{l}$ & \multicolumn{4}{|l|}{960} \\
\hline Sodium adsorption ratio & SAR & meq/1 & \multicolumn{4}{|l|}{5.7} \\
\hline \multicolumn{7}{|c|}{ Irrigation criteria for trace elements (mg/l), Regulatory and Supervision Bureau [14] } \\
\hline Trace elements & Symbol & Units & \multicolumn{4}{|c|}{ Maximum allowable concentration } \\
\hline Aluminium & $\mathrm{Al}$ & $\mathrm{mg} / 1$ & \multicolumn{4}{|c|}{5} \\
\hline Arsenic & As & $\mathrm{mg} / 1$ & \multicolumn{4}{|l|}{0.1} \\
\hline Beryllium & $\mathrm{Be}$ & $\mathrm{mg} / 1$ & \multicolumn{4}{|l|}{0.1} \\
\hline Cadmium & $\mathrm{Cd}$ & $\mathrm{mg} / \mathrm{l}$ & \multicolumn{4}{|l|}{0.01} \\
\hline Chromium & $\mathrm{Cr}$ & $\mathrm{mg} / \mathrm{l}$ & \multicolumn{4}{|l|}{0.1} \\
\hline Cobalt & $\mathrm{Co}$ & $\mathrm{mg} / \mathrm{l}$ & \multicolumn{4}{|l|}{0.05} \\
\hline Copper & $\mathrm{Cu}$ & $\mathrm{mg} / \mathrm{l}$ & \multicolumn{4}{|l|}{0.2} \\
\hline Fluoride & $\mathrm{F}$ & $\mathrm{mg} / 1$ & 1 & & & \\
\hline Iron & $\mathrm{Fe}$ & $\mathrm{mg} / \mathrm{l}$ & 5 & & & \\
\hline Lead & $\mathrm{Pb}$ & $\mathrm{mg} / \mathrm{l}$ & 5 & & & \\
\hline Lithium & $\mathrm{Li}$ & $\mathrm{mg} / \mathrm{l}$ & 2.5 & & & \\
\hline Manganese & $\mathrm{Mn}$ & $\mathrm{mg} / 1$ & 0.2 & & & \\
\hline Molybdenum & Mo & $\mathrm{mg} / \mathrm{l}$ & 0.01 & & & \\
\hline Nickel & $\mathrm{Ni}$ & $\mathrm{mg} / \mathrm{l}$ & 0.2 & & & \\
\hline Selenium & $\mathrm{Se}$ & $\mathrm{mg} / \mathrm{l}$ & 0.02 & & & \\
\hline Vanadium & & $\mathrm{mg} / \mathrm{l}$ & 0.1 & & & \\
\hline Zinc & $\mathrm{Zn}$ & $\mathrm{mg} / \mathrm{l}$ & 2 & & & \\
\hline Microbiology recycled water quality & egulatory a & vision Bure & & & & \\
\hline Microbiology parameters & Symbol & Units & Maximu & able concen & & \\
\hline Faecal coliforms & - & $\mathrm{CFU} / \mathrm{ml}$ & 100 & & & \\
\hline Helminths ova (parasitic worms) & - & $\mathrm{CFU} / \mathrm{ml}$ & $<1$ & & & \\
\hline Intestinal enterococci & - & $\mathrm{CFU} / \mathrm{ml}$ & 40 & & & \\
\hline Sanitary recycled water quality $(\mathrm{mg} / \mathrm{l})$ & ory and $\mathrm{Su}$ & Bureau $[1$ & & & & \\
\hline Sanitary parameters & Symbol & Units & Maximu & able concen & & \\
\hline $\mathrm{pH}$ & - & - & 6 to 8 & & & \\
\hline Biological oxygen demand & BOD & $\mathrm{mg} / 1$ & 10 & & & \\
\hline Total suspended solids & TSS & $\mathrm{mg} / 1$ & 10 & & & \\
\hline Ammonia nitrogen & NH4-N & $\mathrm{mg} / 1$ & - & & & \\
\hline Total phosphorous & & $\mathrm{mg} / \mathrm{l}$ & - & & & \\
\hline Turbidity & & NTU & 5 & & & \\
\hline Residual chlorine & & $\mathrm{mg} / 1$ & 0.5 to 1 & & & \\
\hline Dissolved oxygen & DO & $\mathrm{mg} / \mathrm{l}$ & ${ }^{3} 1$ & & & \\
\hline
\end{tabular}


Table 10 Categorization of AHU A/C condensate water and related terms in codes and standards ([60], p. 6)

Code or standard categories and references Code or standard definitions, categories, and terminology

San Antonio Plumbing Code (SAPC)

[51]

Texas Administrative Code (TAC)

Texas Commission on Environmental Quality (TCEQ

International Green Construction Code (IGCC) International Code Council (ICC [53])
Reclaimed Water. Water from (on-site) sources such as rainwater harvesting, air conditioning condensate collection, carwashes, ponds, lakes, rivers or other sources as approved by the code official. Recycled Water. Water that, because of a tertiary treatment of domestic wastewater by a public agency, is suitable for direct beneficial use or a controlled use that would not otherwise occur. Also referred to as Municipal Reclaimed Water.

Reclaimed Water. Wastewater that has been treated to quality for a suitable use, pursuant to the provisions of Chapter 210 of the TAC and other applicable rules and permits. Reclaimed water that is neither domestic nor municipal is sub-categorized as Industrial Reclaimed Water, which addresses condensate from commercial air conditioning units.

Captured condensate is explicitly included in the general category of Alternate Onsite Non- Potable Water. Condensate is implicitly included in the general category of (on-site) Reclaimed Water. Reclaimed Water. Non-potable water that has been derived from the treatment of wastewater by a facility or system licenced or permitted to produce water meeting the jurisdiction's water requirements for its intended uses. Also known as Recycled Water. Municipal Reclaimed Water. Reclaimed water treated by a municipality. The IGCC explicitly states that air conditioner condensate water is permitted to be collected for use by greywater systems. The common practice of adding air conditioner condensate to a rainwater collection system is not specifically mentioned, although it is not prohibited.

Air conditioner condensate falls under the definition of Alternative On-Site Sources of Water. The term "reclaimed water" is only used in the sense of Municipal Reclaimed Water.

SHRAE. American Society of Heating, Refrigerating and Air-Conditioning Engineers [73]

ASHRAE Standard 191 Efficient Use of Water in Building Mechanical Systems

Standard not released yet (July 2019)

Green Plumbing and Mechanical Code Supplement (GPMCS)

International Association of Plumbing and Mechanical Official [54]

NSF Standards 350 and 350.1

[55]

The purpose of this standard will be to provide baseline requirements for the design of buildings, landscapes, and mechanical systems that minimize the volume of water required to operate HVAC systems, plumbing systems, common building special process systems, cleaning systems and irrigation systems. (a) Balance environmental responsibility, resource efficiency, process efficacy, and community sensitivity, and (b) support the goal of the development that meets the needs of the present without compromising the ability of future generations to meet their own needs.

Air conditioner condensate falls in the general category of Non-potable water Sources, which are non-potable sources of water that include but not limited to greywater, on-site treated non-potable water, rainwater, and reclaimed (recycled) water. More specifically, air conditioner condensate falls in the sub-category of On-Site Treated Non-Potable Water. Reclaimed (Recycled) Water. Non-potable water provided by a water/wastewater utility that, because of treatment of domestic wastewater, meets the requirements of authority having jurisdiction for its intended use.

Air conditioner condensate falls under the general category of Wastewater. The term "reclaimed water" is only used in the sense of Municipal Reclaimed Water.

Table 11 Updated definitions and classifications of MFCS available non-potable water for reuse

\begin{tabular}{lll}
\hline Non-potable water types & Definitions & Classified as
\end{tabular}

Condensate water

(1) Condensed vapours from a heat exchanger also called distillate; (2) the - Reclaimed Water (City of Antonio, 2011); product from a distillation water treatment process ([50], p.118); (3) it - Industrial Reclaimed Water (TCEQ [52]); has the same characteristics as rainwater defined as an Ultrapure/Low - Onsite Reclaimed Water (IGCC [53]); Electrolyte/Low Salinity Water by Duncan et al. [15]; (4) reclaimed - Alternative Onsite Source of Water [73]; water/wastewater: wastewater that has been treated and recovered for - Onsite Treated Non- Potable Water [54]; useful purposes, such as LI ([50], p. 502).

- Wastewater ([14]; [55]).

Food waste effluent

Wastewater: the used water and water-carried solids from a community - Wastewater [14, 52]; (including used water from industrial processes) that flow to a treatment • Greywater ([75]; [76]) plant. Stormwater, surface water and groundwater infiltration may also be included in the wastewater that enters a wastewater treatment plant ([50], p. 658)

Fire sprinkler pump test water Processed water: water used in a manufacturing or treatment process or in or Fire Service Testing Water the actual product manufactured. Water is specifically treated to produce the quality of water needed for the process ([50], p.477)

RORW or reject stream

Reject water/stream: for a pressure-driven membrane process, the concentrated solution containing substances that do not pass through the membrane. The reject stream is also called the concentrate or the con-

centrate stream. For some reverse osmosis systems, it is called the brine • Process water or industrial water [63]. or the brine stream $([50], \mathrm{p} .508)$
- Wastewater [14, 52];

- Process water or industrial water (Victorian Government Department of Health [63].

- Reject/ concentrate stream or brine stream depending on the feedwater water source [77] 
Open Access This article is licensed under a Creative Commons Attribution 4.0 International License, which permits use, sharing, adaptation, distribution and reproduction in any medium or format, as long as you give appropriate credit to the original author(s) and the source, provide a link to the Creative Commons licence, and indicate if changes were made. The images or other third party material in this article are included in the article's Creative Commons licence, unless indicated otherwise in a credit line to the material. If material is not included in the article's Creative Commons licence and your intended use is not permitted by statutory regulation or exceeds the permitted use, you will need to obtain permission directly from the copyright holder. To view a copy of this licence, visit http://creativecommons.org/licenses/by/4.0/.

\section{References}

1. Sommariva C (2006) Synergies between power generation and desalination: economics and social advantages. In: Faugeras et al (eds) Sharing knowledge across the Mediterranean area: towards a partnership for sustainable management of resources and the prevention of catastrophes. IOS Press, Amsterdam; Washington, DC, pp 179184

2. Veerapaneni S, Long B, Freeman S, Bond R (2007) Reducing energy consumption for seawater desalination. Journal of American Water Works Association. Volume 99 (6), pp.95-106. Available at: https://www.awwa.org/publications/journal-awwa/ articleid/15669.aspx (Accessed 15 April 2016)

3. Köppen, Geiger (2018) World maps of Köppen- Geiger Climate Classification. Available at: http://koeppen-geiger.vu-wien.ac.at/ present.htm (Accessed 6 February 2017)

4. Mitchell K (2009) From increasing supply to managing demand. In: Reisz T (ed) Al Manakh 2: Cont'd. Stichting Archis, Amsterdam

5. Food and Agriculture Organization (FAO)- Aquastat (2017) Total renewable water resources per capita per year. http://www.fao.org/ $\mathrm{nr} /$ water/aquastat/data/query/results.html

6. Odhiambo GO (2017) Water scarcity in the Arabian Peninsula and socio-economic implications. Appl Water Sci 7:2479-2492. https:// doi.org/10.1007/s13201-016-0440-1

7. Cordesman AH, Markusen M, Jones EP (2011) Scarcity and strategy in the GCC. Washington D.C: Centre for Strategic and International Studies (CSIS). Available at: https://csis-prod.PRP S3.amazonaws.com/PRP S3fs-public/publication/160615_Gulf_ Stability_Instability.pdf (Accessed 22 January 2016)

8. Seguela G, Littlewood JR, Karani G (2017) Onsite food waste processing as an opportunity to conserve water in a medical facility case study, Abu Dhabi Energy Procedia, Volume 111, pp.548557. Available at: https://doi.org/10.1016/j.egypro.2017.03.217. (Accessed 27 March 2017)

9. Seguela G, Littlewood JR, Karani G (2020) Water resource management in the context of a non-potable water reuse case study in arid climate. Journal of Energy Ecology and Environment. https:// doi.org/10.1007/s40974-020-00169-z. Accessed 18 May 2020.

10. Seguela G, Littlewood JR, Karani G (2020) A GHG metric methodology to assess onsite buildings non-potable water system for outdoor landscape use. Journal of Applied Sciences. Vol.10. Available at: https://doi.org/10.3390/app10041339 (Accessed 16 February 2020)

11. Seguela G, Littlewood JR, Karani G (2017) Eco-engineering strategies for soil restoration and water conservation: investigating the application of soil improvements in a semi-arid climate in a medical facility case study, Abu Dhabi. Journal of Ecological Engineering, Available at: https://doi.org/10.1016/j.ecoleng.2017.07.020 (Accessed 26 September 2017)
12. Seguela G, Littlewood JR, Karani G (2017) A study to assess nonpotable water sources for reducing energy consumption in a medical facility case study, Abu Dhabi. Energy Procedia. Volume 134, pp. 797-806. Available at: https://doi.org/10.1016/j.egypro.2017. 09.532 (Accessed 24 October 2017)

13. Ministry of Climate Change and Environment (2007) Ministerial resolution number (476) of the year 2007 Concerning by-law of AGCC fertilizers and agricultural soil conditioners law. Available at: https://www.moccae.gov.ae/assets/download/e4e8ae38/476. pdf.aspx (Accessed 6 February 2017)

14. Regulatory and Supervision Bureau (2010) Guide to recycled water and biosolids regulations 2010. AD. Available at: http://rsb.gov.ae/ assets/documents/264/regsrwb2010.pdf (Accessed 12 September 2012)

15. Duncan RR, Carrow RN, Huck M, T. (2009) Turfgrass and landscape irrigation water quality: assessment and management. CRC Press, Boca Raton

16. Ayers RS, Westcot DW (1994) Water quality for agriculture. FAO irrigation and drainage paper, 29, rev. 1. Food and Agric. Organization, Rome, Italy. Available at: http://www.fao.org/ DOCREP/003/T0234E/T0234E00.htm\#TOC. (Accessed 6 February 2017)

17. Benton JJ Jr (2012) Plant nutrition and soil fertility manual, 2nd edn. CRC Press, Boca Raton

18. Duncan RR, Carrow RN, Huck M, T. (1999) Treating the cause, not the symptoms: irrigation water treatment for better infiltration. United States Golf Association (USGA) Green Section Record 37(6):11-15

19. Duncan RR, Carrow RN, Huck M, T. (2000) Understanding water quality and guidelines to management. United States Golf Association (USGA) Green Section Record 38(5):14-24

20. Creswell JW, Plano Clark VL (2011) Designing and conducting mixed methods research, 2nd edn. Sage, London

21. Creswell JW, Creswell JD (2018) Research and design qualitative, quantitative and mixed approaches. Sage Publication, Thousand Oaks

22. United States Environment Protection Agency (2012) Water sense at work, best management practices for commercial and institutional facilities: onsite non-potable water sources (chapter 8). U.S EPA, Washington DC

23. Healthcare Environmental Resource Center (2015) Facilities management- water conservation. Available at: http://www. hercenter.org/facilitiesandgrounds/waterconserve.cfm (Accessed on 5 July 2015)

24. United States Environment Protection Agency (2015) Hospitals. Available at: http://www3.epa.gov/watersense/commercial/types. html\#tabs-hospitals (Accessed 23 November 2015)

25. Carrie R, Rich JKS, Wadhwa SS (2013) Sustainability healthcare management a leadership imperative. Routledge, Practice Greenhealth. New York

26. Falkenmark M, Widstrand C (1992) Population and water resources: a delicate balance. Population Bulletin, Washington

27. Food and Agriculture Organization (FAO) (2008) Coping with water scarcity: an action framework for agriculture and food security. ISBN 978-92-5-107304-9. http://www.fao.org/3/i3015e/i3015e. pdf

28. Dawoud MA (2008) Strategic water reserve: new approach for old concept in GCC countries. Abu Dhabi, Environment Agency, Abu Dhabi (EAD)

29. Ministry of Environment and Water (2010) United Arab Emirates water conservation strategy. Available at: http://extwprlegs1.fao. org/docs/pdf/uae147095.pdf (Accessed 6 February 2017)

30. Regulation and Supervision Bureau (2013) Supporting the AD economic vision 2030. AD: RSB Available at: Available at: http://rsb. gov.ae/assets/documents/770/vision2030may2013.pdf (Accessed 24 January 2017) 
31. Regulation and Supervision Bureau (2015) Technical report. AD: RSB [online] Available at: http://rsb.gov.ae/en/publications/detail/ technical-report-2015 (Accessed 27 April 2017)

32. Environment Agency-AD (2013) Maximizing recycled water use in the emirate of Abu Dhabi. Abu Dhabi: EAD. Available at: https:// www.ead.ae/Publications/Maximizing\%20Recycled\%20Water\% 20Use\%20in\%20the\%20Emirate\%20of\%20Abu\%20Dhabi/ recycled-water-PB-Eng.pdf. (Accessed 30 January 2014)

33. Dawood MA, Sallam OM, Abdelfattah AA (2012) Treated wastewater management and reuse in arid regions: $\mathrm{AD}$ case study. In: $10^{\text {th }}$ Gulf Water Conference. Bahrein, Manama

34. Jasim SY, Saththasivam J, Loganathan k, Ogunbiyi O (2016) Reuse of treated sewage effluent (TSE) in Qatar. Journal of Water Process Engineering 11:174-182

35. Girardet H (2004) Cities people planet. Willey, West Sussex

36. Dalahmeh S, Baresel C (2014) Reclaimed wastewater use alternatives and quality standards. Stockholm: Department of Energy and Technology, Swedish Environmental Research Institute. Available at: http://sjostad.ivl.se/download/18.1f96676d145d7c937412444/ 1400791505237/C24.pdf. (Accessed 4 September 2017)

37. Salem AA, Wasfi IA, Al-Nassibi SS (2012) Trace determination of $\beta$-blockers and $\beta 2$-agonists in distilled and waste-waters using liquid chromatography-tandem mass spectrometry and solid-phase extraction. J Chromatogr B 908:27-38

38. Al Kuttab J (2017) Treated sewage water for irrigation in Capital by 2030. Available at: https://www.khaleejtimes.com/nation/abudhabi/treated-sewage-water-for-irrigation-in-capital-by-2030. (Accessed 3 March 2017)

39. Environment Agency- AD (2014) The water resources management strategy for the Emirates of AD 2014-2018. AD: EAD. Available at: . (Accessed 30 January 2014)

40. Cardno (2014) Greywater/condensate water risk assessment report. [unpublished manuscript]. AD: Cleveland Clinic AD

41. Jarrar A (2017) Utilization of treated sewage effluent for landscape irrigation in AD City. In: Future Landscape \& Public Realm Conference. AD

42. Health Authority AD (2011) EHSMS standard 12- water quality

43. Department of Municipal Affairs and Transport (2013) AD international building code: plumbing systems (chapter 29). DMAT, Abu Dhabi, p 501

44. Environment Agency AD (2009) Uniform plumbing code of $A D$. AD: EAD. Available at: https://www.ead.ae/Documents/ RESEARCHERS/Uniform\%20plumbing $\% 20$ code $\% 20$ o f $\%$ 20abu\%20dhabi\%20emirate.pdf (Accessed 30 January 2014)

45. Urban Planning Council (2010) Pearl building rating system: design \& construction, version 1.0, April. AD: UPC. Available at: https://www.upc.gov.ae/en/publications/manuals-and-guidelines/ public-realm-rating-system (Accessed 04 April 2018)

46. Dubai Municipality (2010) Green building regulations \& specifications. https://www.dewa.gov.ae/ /media/Files/Consultants\% 20and\%20Contractors/Green\%20Building/Greenbuilding_Eng. ashx. (Accessed 30 June 2015)

47. Health Authority AD (2012) EHS regulatory instrument code of practice EHS RI- COP 12- prevention and control of legionnaires disease. Version 2. AD: OSHAD [online] Available at: https:// www.oshad.ae/ (Accessed 15 January 2016)

48. ASHRAE. American Society of Heating, Refrigerating and AirConditioning Engineers (2000) Guideline 12-2000 - Minimizing the risk of legionellosis associated with building water systems. Available at: https://www.ashrae.org/resources\%2D\% 2Dpublications/bookstore/ansi-ashrae-standard-188-2015legionellosis-risk-management-for-building-water-systems (Accessed 6 February 2017)

49. Wilchelns D, Qadir M (2015) Achieving sustainable irrigation requires effective management of salts, soil salinity, and shallow groundwater. Agricultural Water Management. Volume 157, pp
31-38. Available at: https://doi.org/10.1016/j.agwat.2014.08.016 (Accessed 25 February 2016)

50. American Water Works Association (2010) The water dictionary: a comprehensive reference of water terminology. 4th ed. McTigue, N.E., Symons, J.M. ed. Washington DC: AWWA

51. City of San Antonio (2011) San Antonio City Code, Chapter 10, Article IX: Plumbing code. Available at: https://library.municode. $\mathrm{com} / \mathrm{tx} / \mathrm{san}$ antonio/codes/code of ordinances?nodeId=PTIICO CH10BULACO_ARTIXPLCO (Accessed 6 February 2017)

52. Texas Commission on Environmental Quality (2017) Texas administrative code, Title 30, Chapter 210. Available at: http://txrules. elaws.us/rule/title30_chapter210 (Accessed 25 February 2016)

53. International Code Council (2018) International Green Construction Code (IGCC) with water efficiency provision

54. International Association of Plumbing and Mechanical Officials (2015) Green Plumbing and Mechanical Code Supplement (GPMCS). Available at: http://www.iapmo.org/WEStand/Pages/ GreenPlumbingandMechanicalCodeSupplement.aspx (Accessed 6 February 2017)

55. NSF International (2011) NSF/ANSI Standard 350 onsite residential and commercial water reuse treatment systems. Available at: http://www.nsf.org/newsroom pdf/SU PSD Magazine Article LT_EN_350_351_LSU-2722-0911.pdf (Accessed 6 February 2017)

56. Seguela G (2018) Implementation and evaluation of an outdoor water conservation strategy for hospital decarbonisation in an arid climate. Unpublished Professional Doctorate in Engineering Thesis, Cardiff Metropolitan University

57. O'Leary Z (2014) Doing your research project, 2nd edn. Sage, London, New Delhi

58. Yin RK (2014) Case study research: design and methods, 5th edn. Sage, London, New Delhi

59. Atura (2013) Handbook for reusing or recycling RORW from haemodialysis in healthcare facilities: a project by North West Dialysis Service. Melbourne: Melbourne Health. Available at: https://waterportal.com.au/swf/images/swf-files/62r-2056handbook.pdf (Accessed 6 February 2017)

60. Glawe D (2013) San Antonio condensate collection and use manual for commercial buildings. San Antonio: City of San Antonio. Available at: http://www.saws.org/conservation/commercial/ Condensate/docs/SACCUManual_20131021.pdf. (Accessed 04 April 2015)

61. Anon (2017) Interview with the biochemical engineer/researcher at Masdar Institute of Science and Technology, 24, October 2017

62. Anon (2017) Interview with the laboratory technician at MFCS, 22, October 2017

63. Victorian Government Department of Health (2009) Guidelines for water reuse and recycling in Victorian healthcare facilities. Available at: https://www2.health.vic.gov.au/Api/ downloadmedia/\%7B949656D2-00DA-486E-B45084C75D71A0BF\% 7D (Accessed 25 February 2016)

64. Regulation and Supervision Bureau (2014) The water quality regulations (Fourth Edition). Regulation and Supervision Bureau. AD. Available at: http://rsb.gov.ae/assets/documents/366/ regswaterquality4thedition.pdf (Accessed 12 September 2012)

65. Landschoot $P$ (2013) Irrigation water quality guidelines for sports turf. Field Science, Sports Turf. Available at: http://sturf.lib.msu. edu/article/2013oct18.pdf (Accessed 10 January 2017)

66. Ali Khan SA, Al-Zubaidy SN (2013) Conservation of potable water using chilled water condensate from air conditioning machines in hot \& humid climate. International Journal of Engineering and Innovative Technology 3:182-188

67. Lawrence T, Darwich AK, Means JK, Boyle S (2013) ASHRAE green guide. Design, construction, and operation of sustainable buildings, 4th edn. ASHRAE, Atlanta 
68. Licina D, Sekhar C (2012) Energy and water conservation from air handling unit condensate in hot and humid climates. Energy and Buildings, Volume, 45, pp.257-263. Available at: https://doi.org/ 10.1016/j.enbuild.2011.11.016 (Accessed 6 February 2017)

69. Loveless KJ, Ghaffour N, Farooq A (2013) Collection of condensate water: global potential and water quality impacts. Water Resource Management. Volume 27 pp.1351-1361

70. Bryant JA, Ahmed T (2008) Condensate water collection for an institutional building in Doha, Qatar: an opportunity for water sustainability. In: Proceedings of the Sixteenth Symposium on Improving Building Systems in Hot and Humid Climates. Plano, Texas: IJEIT. Available at: http://www.ijeit.com/Vol\%203/Issue\% 202/IJEIT1412201308_34.pdf (Accessed 6 February 2017)

71. Cabrera R (2014) Non-potable water sources for urban landscape irrigation in arid regions. Journal of Arid Land Studies. Volume 24 (1), pp.89-92

72. Kant S, Jaber F, Qiblawey H (2012) A/C condensate for water reuse: an approach towards environmental sustainability in Doha. In: American Society of Agricultural and Biological Engineers Annual International Meeting. Dallas: American Society of Agricultural and Biological Engineers. Available at: https://www. scopus.com/record/display.uri?eid=2-s2.0-84871779776\&origin= inward\&txGid=afa8008826f25b73ba602558217b2506

73. ASHRAE. American Society of Heating, Refrigerating and AirConditioning Engineers (2009) ASHRAE Standard 189.1-2009, Standard for the design of high performance green buildings except low-rise residential buildings

74. ASHRAE. American Society of Heating, Refrigerating and AirConditioning Engineers (2018) ASHRAE Standard 191, Efficient use of water in building site and mechanical systems. Available at: http://spc191.ashraepcs.org/ (Accessed 14 May 2018)

75. Wong J, Patten Z, Griffith-Onnen I (2013) On-site systems for processing food waste. A report to the Massachusetts Department of Environmental Protection. Available at: http://www.mass.gov/ eea/agencies/massdep/recycle/reduce/massdep-food-waste-finalreport.pdf (Accessed 3 March 2016)

76. Neale Z (2013) Analysis of biodigesters and dehydrators to manage organics on-site, BioCycle. Volume 54 (10), p. 20. Available at http://www.biocycle.net/2013/10/25/analysis-of-biodigesters-anddehydrators-to-manage-organics-on-site/ (Accessed 6 February 2017)

77. American Water Works Association (2010) Water treatment: principles and practices of water supply operations, 4th edn. AWWA, Denver

78. Buzzle (2013) Distilled water pH Level. Available at: https:// sciencestruck.com/distilled-water-ph-level (Accessed 6 February 2017)

79. World Health Organization (2003) Heterotrophic plate counts and drinking-water safety: the significance of HPCs for water quality and human health. Available at: http://apps.who.int/iris/bitstream/ 10665/42612/1/9241562269.pdf?ua=1 (Accessed 25 May 2017)

80. World Health Organization (2011) Guidelines for drinking-water quality. $4^{\text {th }}$ ed. Available at: http://apps.who.int/iris/bitstream/ 10665/44584/1/9789241548151_eng.pdf (Accessed 25 February 2016)

81. Wu TY, Mohammad AW, Lim SL, Lim PN, Hay JXW (2013) Recent advances in the reuse of wastewaters for promoting sustainable development. In: Sharma S, Sanghi R (eds) Wastewater reuse and management. Springer, New York; London

82. Anon (2017c) Interview with the senior director sustainability on Skype, 29 October 2017

83. Bedbabis S, Ben Rouina B, Boukhris M, Ferrara G (2014) Effect of irrigation with treated wastewater on soil chemical properties and infiltration rate. Journal of Environmental Management. Volume 133, pp.45-50. Available at: https://doi.org/10.1016/j.jenvman. 2013.11.007 (Accessed 10 December 2017)

84. United States Environment Protection Agency Office of Water (2012) 2012 guidelines for water reuse. Available at: https:// watereuse.org/wp-content/uploads/2015/04/epa-2012-guidelinesfor-water-reuse.pdf (Accessed 03 January 2017)

Publisher's Note Springer Nature remains neutral with regard to jurisdictional claims in published maps and institutional affiliations. 